\title{
A CASE OF SUDDEN DEAFNESS WITH COMPLETE RECOVERY
}

By

Ichiro KIRIKAE, Tsutomu MATSUZAKI and Tsunzmasa SATO

From Department of Oto-Rhino-Laryngology, Faculty of Medicine, University of Tokyo

A 55-year-old male had a slight attack of cold and ear fullness and was found to be severely deaf in the left car when he awoke in the next morning.

The audiogram showed typical volley-type hearing loss up to $75 \mathrm{~dB}$ in the middle frequency range. Recruitment was positive. In the affected ear diplacusis was found and the directional acuity of hearing was impaired in that side. A marked loss for the distorted speech discrimination was revealed. These audiologic findings suggested socalled endolymphatic hydrops.

The hearing loss recovered to be completely normal in the following two weeks, and recruitment and diplacusis were gradually improved.

The etiology and pathogenesis of sudden deafness were discussed on referring to the previous clinical reports and investigations of the inner ear pathology.

\section{特異な聴力損失像を呈した突発性難聴の一治験例}

\section{一一突発性難聴の病因, 病態論—}

\author{
東宗大学耳翼晒㮢科学教室 \\ 切替 替郎
}

第 1 章 緒 空

突発性蜼㯖恃原因不明の感音性難聴である。それは近 年雁々遭遇する疾患であり，その症例報告も多数累程を みるに拘らず, その病因，病態に関しては推測の域を出 ない、しかしながらその病像の詳細な検索は感音性難聴 の族態生理研究上さわめて豊富な示咬を与えるのみなら ず，広く一般聴覚機丵解明に貴重な資料を提供すると思 われる。

今国，我々は與味ある聴力像，臨休絟過を示した突発

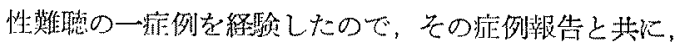

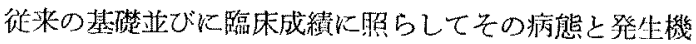

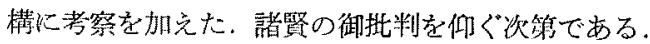

\section{第 2 章 症例}

患者：50才。男子。

主訴：在耳閉塞长及び難㯖.

既往歴：7年前涂道の穕古中忹倒し，後頭部を強打, 2 分閏位失神したことがある。それ以外には生来健康に

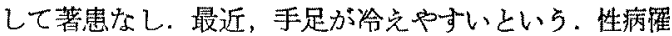

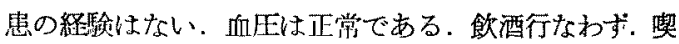
煙は1日 20 本位.

家族歴：特記すべきことなし．

現病歴：患者は警察官で職名は讱查部長. 職務内容 は蓖攞係として交番勤務の巡查を巡回監督与る仕事であ る、終日勤務を原則としかなりの激济である。

9 月中頃来，週休もとらずに連日勤務し，また部下の 仕杗の上で精神的苦労が重なり，心身共に過労気昧であ つだ.9月26日午後，3時間位㻎類作成の業務を行なつ ていたとこる風邪をひき始めたよらな恶感があり，同時 に左耳に突然閉塞感が起つた。 また，全身の浮遊感が生

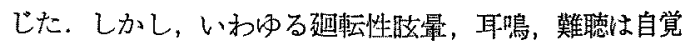
しなかつた，当日は仮当直で仮眠の際，時計の秒針の音 を徽かに聞いたことを記憶している。

9 月 27 日午前 6 時, 起㕅時左耳閉塞感あり, 秒針の 音が全く關えず，左耳に軽度の耳鳴を感した，悪感及び 


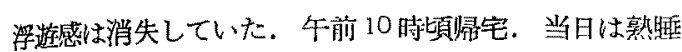
した.

9月28日，当科外来初診。往路多少の覀心があつた。

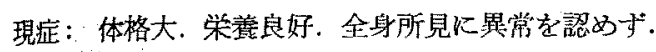
和王 $180 \sim 130 \mathrm{mmHg}$.

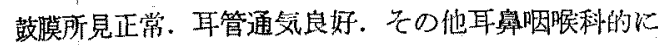
特別異常所兒を認めない。

病歷経過：初搒当日入院，主要金身検查所見次の如

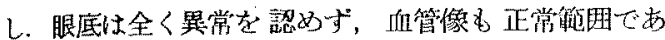

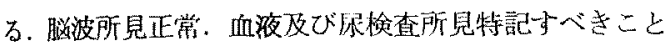

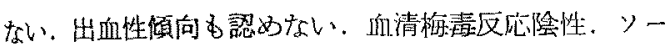
ンテストは減少率 $0 \%$ で正常. 自律神経機能検查. ピロ カルピン，アトロビン，アドレナリン各検查成績は正常 範用であつた，血清中セロトニン量す正常，爪林毛細管 榆查，病的变化心見られない。

\section{聴賞検查成績}

(I) 純音德力検査

本症例では発病後 3 日目より連日聴力を泪定すること がでさた。

純音聴力間做は著しい恢復を示した。艺の恢復過程は 図1の如くである。9月28日（初猃日，第3病日）に は気骨導㯖力共に公型の聴力損失を呈している，その中 心部は $1000 \mathrm{cps}$ で $75 \mathrm{~dB}$ の閶値上昇を示した。 そして それより低及び高音域ではほぽ対称性に間值の下降が見 られ，雨端の $125 \mathrm{cps}, 8000 \mathrm{cps}$ ではそれぞれ 20dB， 35 $\mathrm{dB}$ の㯖力椇失が㒛められた。

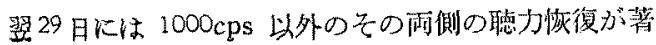

しく，その聴力像は楔型を是してきた３0日（第5病

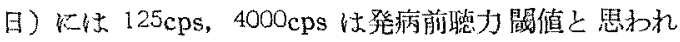
る者側耳と同じ值にまで恢復し，以後 $1000 \mathrm{cps}$ を的心

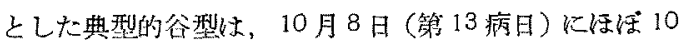

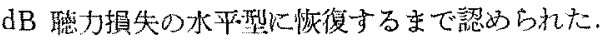

一力，右倪耳性 $4000 \mathrm{cps}$ 以上で約 $20 \mathrm{~dB}$ の聴力損失 を認めたが，これ体年令变化に上るものと思われる。

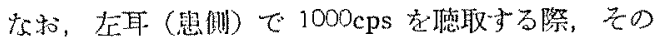

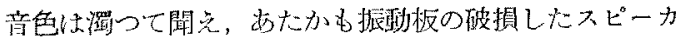
一から音を聼取しているようであると琵見した，をれは 䋉竟では $800 \mathrm{cps}$ の音出に近い上い5.しかし，800 cps， $1500 \mathrm{cps}$ 及びその他の周波数純音では在耳同㥞の登九た 音が聞えたという。

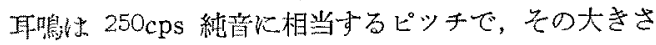
は右耳の 15dBSL と师嘢した。

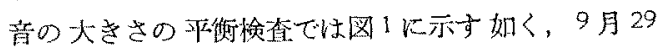
日（第 4 病日）に $250 \mathrm{cps}, 1000 \mathrm{cps}, 4000 \mathrm{cps}$ に拈いて特

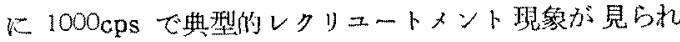

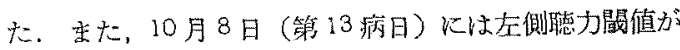

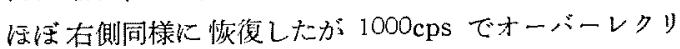
ニートメント現象が珰好5れた。しかし，11月4日（第 40 病日)にはレクリニートメント現象は隊性であつた。

T.T.D.T 検査は $500 \mathrm{cps}, 1000 \mathrm{cps}, 2000 \mathrm{cps}$ で陰性.

SISI 検查借 $1000 \mathrm{cps}, 30 \mathrm{dBSL}$ で $30 \%$ を示し, 陰性.

(II) 自記オージオメトリー（図 2)

$1000 \mathrm{cps}, 4000 \mathrm{cps}$ と歹に3 分間䏇取で TTS を認めな い，また，雨周波数 $80 \mathrm{~dB} ， 1$ 分間奂荷前後の振幅变化

図 1 左図は聴力の回復過程を示す，右図は第3病日のレクリニートィント現象陽珄を示す。
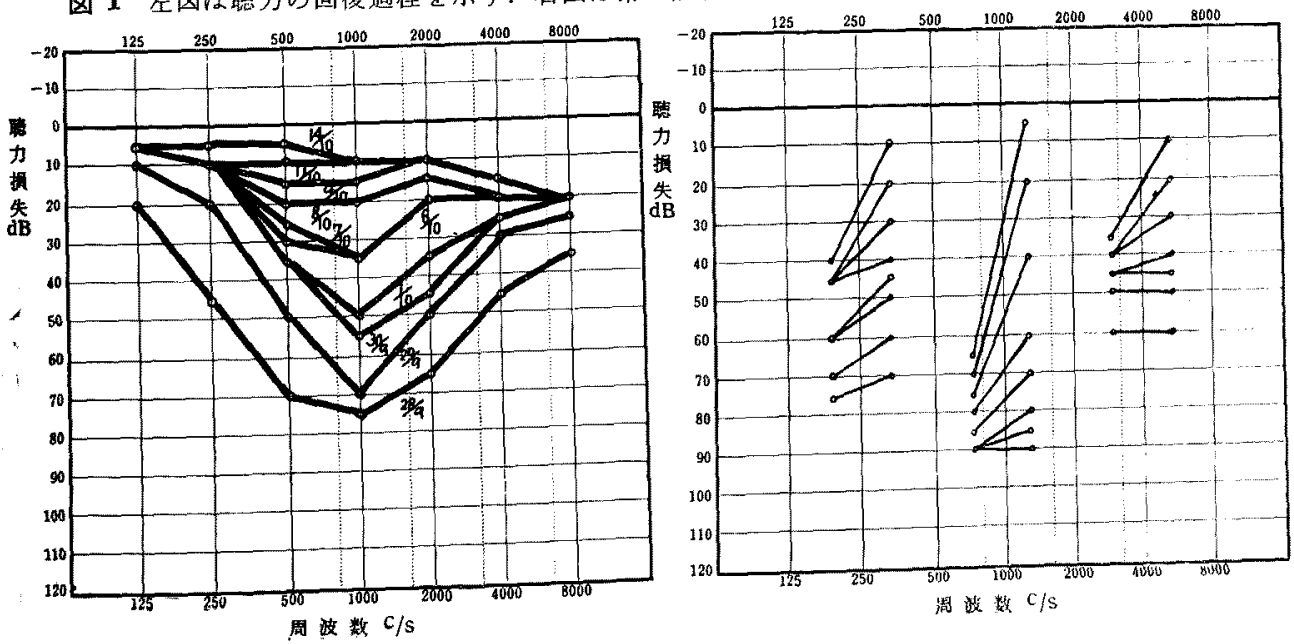
图 2 自記才一ジオメ卜リ一成躀

A) 断続音と持続音との比校（第 4 病日）
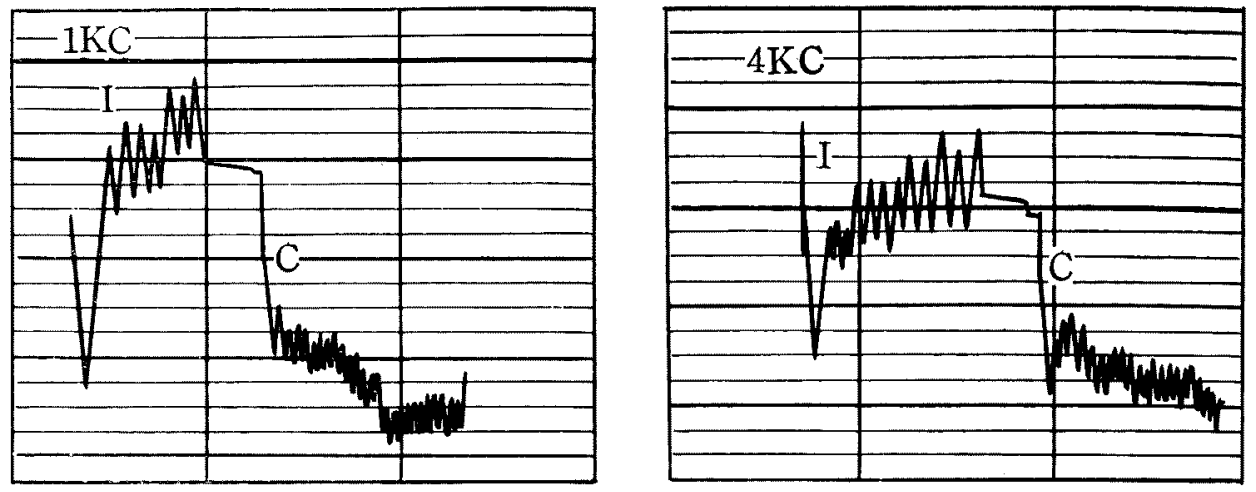

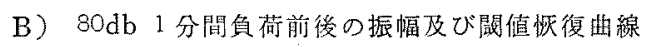

i) 左耳（第6 病日）

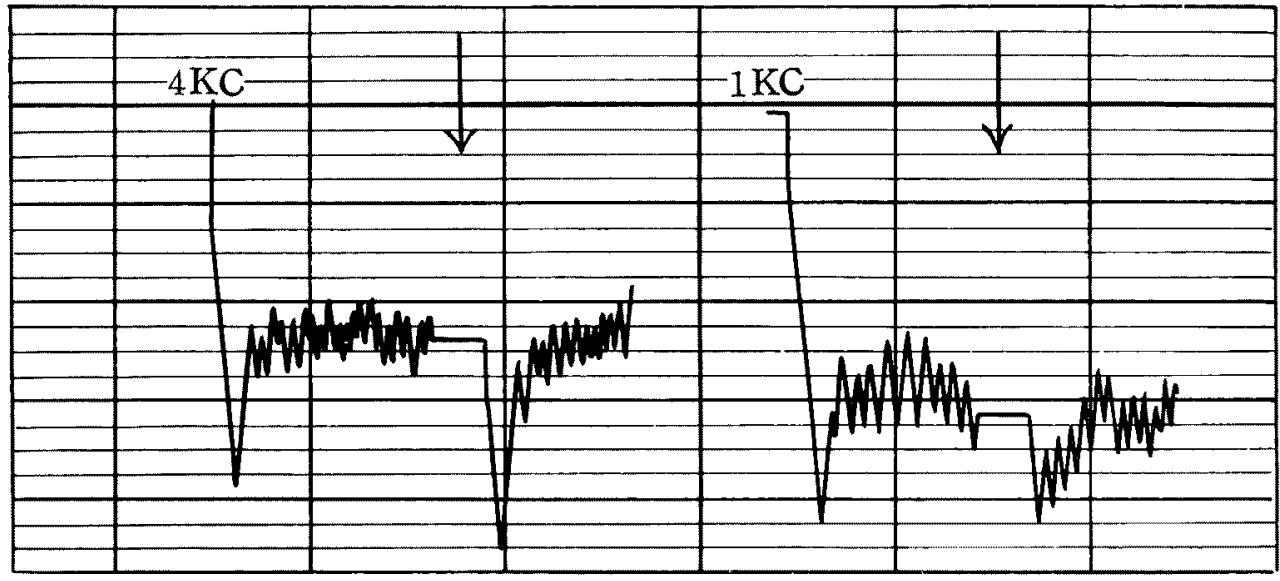

ii) 左耳（第19病日）

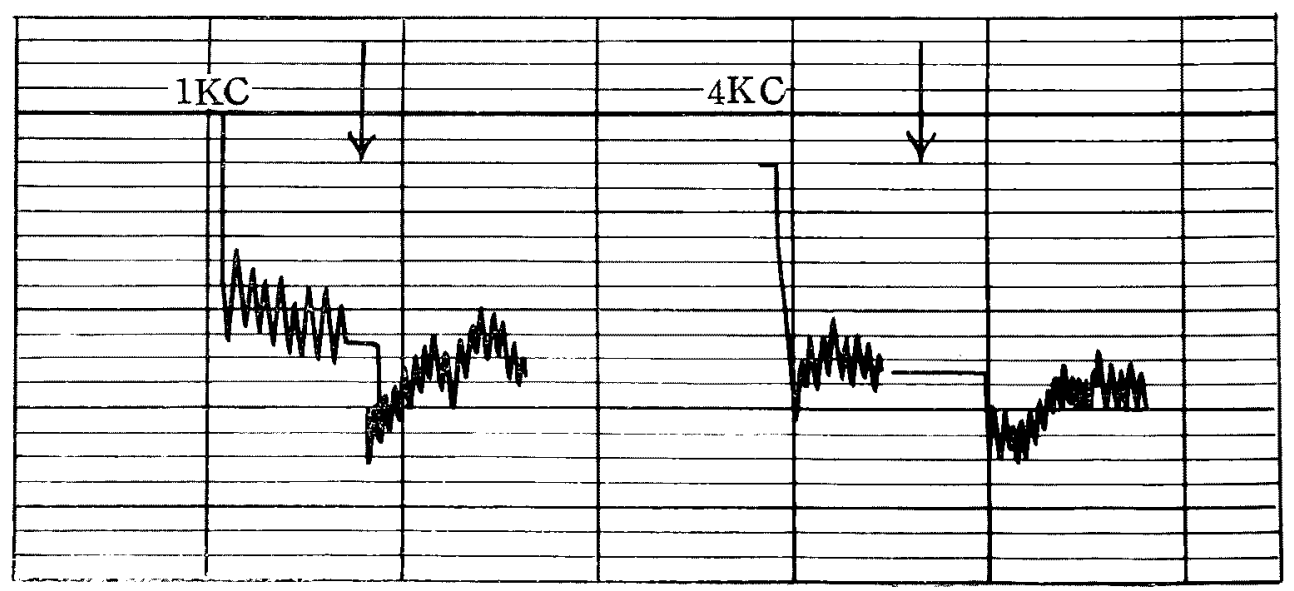


及び闒值恢復曲線をみると振幅は6〜8dB で負荷前後に 著明な変化は見られず，著者らの分類の D 型を呈した。 この場合，断続音を用いると閵值は約 15〜20dB 下降 し，振幅摭大 $(5 \mathrm{~dB} \rightarrow 10 \mathrm{~dB})$ が認められた。

〔III)方向感検查

10月1日（第6病日）成績. 音源として $250 \mathrm{cps}, 500$

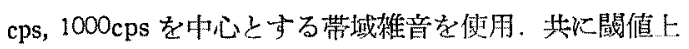
40dB 附近の音の大きさで可衡をとり，音像を正中に結 び两耳間時間差による方向感升別䦨値を湘定した. 右耳 先行音の場合はいずれも $2 \mathrm{~cm}$ 以内で正常であるのに反 し, 左耳先行では $3 \mathrm{~cm}$ から $8 \mathrm{~cm}$ に病例に拨大してい た。摭大は $1000 \mathrm{cps}$ で最大であつた。

この傾向は10月8日（第 13 病日）にも認められたが， 10月14日（第 19 病日）に情側子す $2 \mathrm{~cm}$ 以内で正常 とならた.

\section{〔V〕 語音明膫度検査}

10月1日（第6 病日）成紿. 明膫度閵值は右耳. $16 \mathrm{~dB}$, 左耳 $38 \mathrm{~dB}$ であつた．普通語音明膫度は表 1 亿示す如 く，最高明睧度は右耳が 96\% (45dB), 左耳が 90\% (60 dB) であつた. ノイズ語音明瞭度は $1000 \mathrm{cps}$ パンド， イズ $60 \mathrm{~dB}$ の下で右耳 $64 \%$, 左耳 $30 \%$ で特に左耳の低 下が認められた。

第 1 曾通語音明膫度曲線（第6 病日） 昭和 40 年 10 月 2 日 㛟者 T.S.

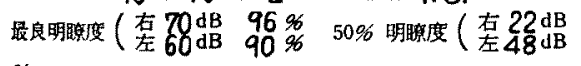

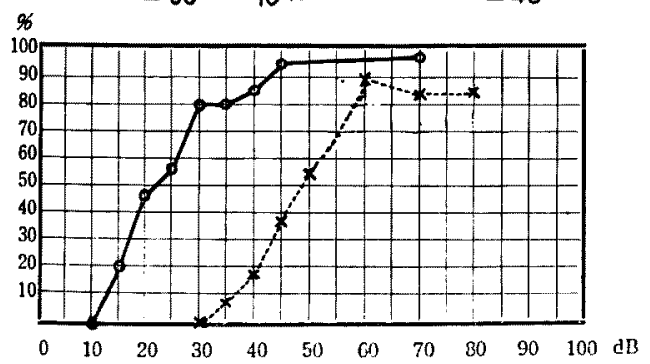

歪語音明膯度（10月2日（第7病日）施行 表2)で は切断語音，周波数企語音及び分割語音検查を行なつた が，いずれも左耳に軽度の低下が認められた。

しかし，これらの語音明瞭度検查成續は11月4日（第 40 病日) には左右ともに正常範囲に恢復していた。

\section{[V] 特殊検查}

音刺激頻度把握検查では左耳は右耳に比し，多少の機 能低下を示した。しかし，時間認識検査では左右差は摁

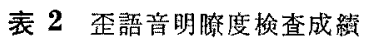

（符 7 病日施行，（）内は正常値）

\begin{tabular}{|c|c|c|c|}
\hline \multirow{2}{*}{ 切断語音明膫榄 } & \begin{tabular}{|r} 
右 \\
$(70 \mathrm{~dB} \mathrm{SL})$ \\
\end{tabular} & $\begin{array}{r}\text { 耳 } \\
\text { 空 } \\
85 \mathrm{~dB} \mathrm{SL}\end{array}$ & 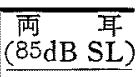 \\
\hline & $42 \%(67)$ & $34 \%(62)$ & $66 \%(93)$ \\
\hline \multirow{4}{*}{ 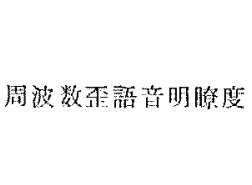 } & & 有 前 & 左 \\
\hline & 1.2KCLP & $26 \%(85)$ & $12 \%(85)$ \\
\hline & $1.7 \mathrm{KCHP}$ & $64 \%(85)$ & $34 \%(85)$ \\
\hline & AP. & $94 \%(95)$ & $78 \%(95)$ \\
\hline \multirow{2}{*}{ 分踓浯音明膫度 } & 右耳前穊 & 左耳後節 & 雨 \\
\hline & $36 \%(58)$ & $9 \%(15)$ & $39 \%(63)$ \\
\hline
\end{tabular}

められなかつた（9月29日（第 4 病日）施行).

\section{第 3 章 総括並ひに考按}

笑発珄難聴は原因不明の感音性難聴を主徵とする一症 候群である。時に胘霍を伴ならことがあるが，その症状 が反復することのないのが特徽である。

その発病の根底に恃常になんらかの基濋疾㭧，発生機

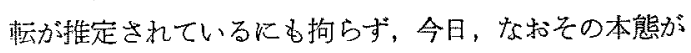
解明されていない，それにはいくつかの理由がある。そ の一つは笑発性難聴自体が致命的疾患でなく，またその ような疾患に随伴するるのでないため容易にその病理剖 検例が得られず，その病態が正確に把握されないことで ある. その推移はメニェール病の場合, その病理組織の 報告例の增加に伴ない病態の理解が念速に進展した事実 からも首肯け上ら。その第2 とは本疾患の臨床像の複雑 さが挙げられよう，その症状，経過，予後とさわめて多 彩で，個々の症例でも多様性に富むので病因を少数の要 素で分析するのが非常に困難である．そして最後に強い て述べるならば，側頭骨の殼壁の中に微細な蔵器として 和さまるこの感覚器としての比類なき位置的，機能的特 異性が，進行しつつある病変過程を追究せんとする手段 を拒んでいたことが指摘できるであるう。

さて，我々は今回，きわめて興味ある谷型聴力像を呈 し，しかるその恥力障害が完全に恢復した突発性難聴の

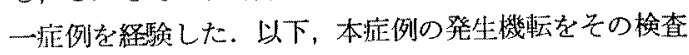
成績亚びに臨床経過から考察を加えてみたい。

突発性難㯖の歴实的推移林古く Kobrak 1) (1922) の "angioneurotische Oktavuskrise", De Kleyn 2)(1944) $の$ "Sudden complete or partial loss of function of the octavus-system”などの 記截があるが，今日の “Sudden deafness”の名称は1949年 Rasmussen ${ }^{3)}$ 
使用したのが简矢である。その後，本疾患に関して諸坐 周，本邦以多数の翰告の集䅡がめる。その間の経緯仙 崎 ${ }^{4}$ ) (1963), Bosatra et al 5) (1961) の記述に詳しいの でここには割愛する。

ただ，覧㦿家をして突発性難聴に最も興味を抱がし めるの虾の病因ならびに病熊であるら。それらに閣し ては既に多くの考按がなされ，諸説が提比されている。

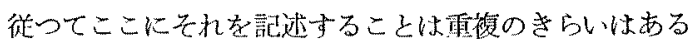

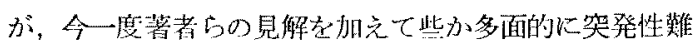
聴の病因 (Etiology), 病態発生機序 (Pathogenesis) 及 び病理 (Pathology)について考察を試みてみたいと思 5 .

\section{(1) 突発性嚾聴の病因諭}

突発性難聴山原因不明の一症候群である。そ饥故，い くつか提唱されている要素恃すべて释駼的に推测，若接 されたるのであるのは当然でする，先ず，てれらを列挙

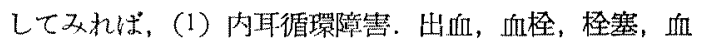

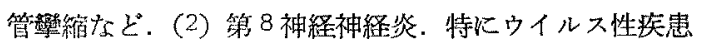
に上るもの. (3) 螖牛内压の急激な兄進. (4) 内耳の中 毒性病変. (5) その他. 全身疾患によるものなど.

これら病因圭奒来の報告の主な見解により分類すると 表了の如くなる。また，病因の作用機構を著者らの考察 から図解寸れば図3の加くなると思われる。

次に，突発性難㯖に打けるそれら病因の可能性につい てやや敷胤て述べてみる。

\section{(1) 血管幦彗}

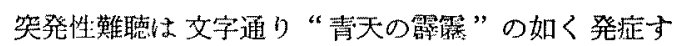
る. 住つてその栐相を脳卒中のそれとの類推から血管障 書を想像するのは自然の思考過程であろう。ささらに本疾 患孝血管障害とする大きな論拠には内耳動脈が終末動脈 であることが挙げられる，聴器は硬い骨壁に保 護される代償としてその血行を終末動脈に低存 するといら宿命を負つた。この事実より推せば

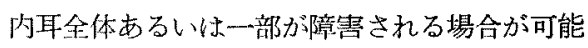
である。

さて，血管障窝で先才゙考えられるのは出血で 污万．Kobrak 1)(1922) は笑発性難聴には出 的性韭因がなくても常に出血を考虑すべきであ ると述へたが，その後の都告で純籸な突発性難 聴の症例に出血性素因を見出したものはない （血管透過性元准の報告はある）。

一方，突発難㯖の発病年令を质るに Rasmu$\operatorname{ssen}^{3)}(1949)$ は 18 例中 8 例は 40 才以下, 10

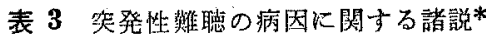

\section{(I) 血管㜔書を主とするるの}

Habermann 17) (1898), Escat 18) (1906), Kobrak 1) (1928), de Kleyn 2) (1944), Rasmussen 3) (1949), Lindsay et al ${ }^{15)}$ (1950), Hilger 22) 24)(1950, 1951), Fowler ${ }^{6}$ (1951), Saltzman et al ${ }^{19}$ (1952), Heller, et al 46) (1955), Schroeder 9) (1955), Beickert 47) (1956), Hallberg 7) 48)(1956, 1957), Lieberman ${ }^{58)}$ (1957), van Canegham ${ }^{49)}$ (1958), Lenhardt ${ }^{38}$ ) (1958), Debain 50)(1958), Wilmot 51)(1959), Walander et al 52) (1960), Bosatra et al 5) (1961), Kirikae et al ${ }^{20)}$ (1962).

（II） 主としてウイルス感染による 第 8 神経炎とするもの

Moe ${ }^{53)}$ (1947), Rasmussen ${ }^{3)}$ (1949), Lindsay et al 15) (1950), Sterkers ${ }^{64)}$ (1955), Heller et al ${ }^{46)}$ (1955), Bocca 29) (1956), van Dishoeck et al 20) (1957), Svane-Knudsen ${ }^{8)}$ 55) (1957 a, b), Möller et $\mathrm{a}^{25}$ (1957), Bierman ${ }^{56)}(1957)$, Brown ${ }^{57)}(1957)$, Lieberman ${ }^{58)}$ (1957), Debain ${ }^{50)}$ (1958), Lindsay 59)(1959), Saunders et al 28)(1959), Wilmot ${ }^{\text {51) }}$ (1959), Jerger et al ${ }^{60)}(1961)$, Schuknecht et al 16)(1962), Harbert et al ${ }^{61)}(1964)$. .

\section{(而) 蝸牛内无宇進とするるの}

Mygind 35) 62) (1947, 1951), Opheim ${ }^{31)}$ (1950), Nielsen ${ }^{36}$ ) (1953), Hallberg $\left.{ }^{7)} 48\right)$ (1956, 1957), Lenhardt ${ }^{88)}$ (1958).

\section{* 報告者の主な見解に従つて分類して。}

（1）は多くの病因を総括した。

（II）は（I）の結果とする見解も多い，

图 3 突発性難聴の病因と発生機序

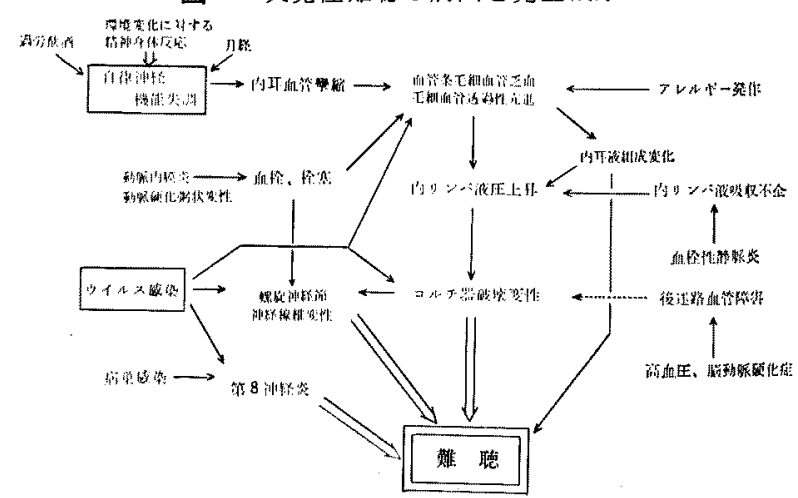


例は以上と述へ，Fowler ${ }^{6)}$ (1951) は26例中77\%は 40 才以下といい, Hallberg ${ }^{7}$ (1956) は178 例の斑均が $49 才$, Svane-Knudsen ${ }^{8)}$ (1957 a) 洁 21 例 平均方: 45 才とし，Schroeder ${ }^{9}$ (1955) は 50 才代が多いと報告し

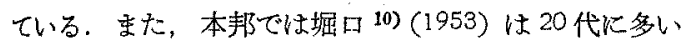

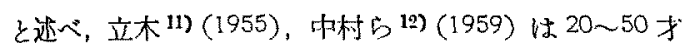
の間が大部分といい，切替ら ${ }^{19}$ (1960) は30才代が最 む多いとしている，要た吉田ら 14) (1960) はとの131 例 の報告加ら男子は30代次いで20 代が多いのに刘し，女 子は20代が最多で次に50 代が多かつたと拈べている。

これらを通覧する諸外囷でけ４0〜50 才代に最も多く。 本邦ではそれより約10才位若年のものに多い上らであ る、いずれにしてもその年令分布は動脈硬化あるいは归了 状变性など血管性変化が発来する年代とは隔りがあり，

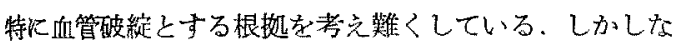
がら，他方各症例の最年長者をみてみると Lindsay et $\mathrm{al}^{15)(1950)}$ の78才，堀口10)(1953)の72才，SvaneKnudsen ${ }^{8)}$ (1957), Schuknecht et al ${ }^{10)}$ (1962) D 65 才などのかなりの高令者があり， Rasmussen ${ }^{3)(1949)}$ す著明な動脈硬化と高血王を示した 3 症例を赫告して掟 り，内耳出血の可能性も全くは否定できないであるら. 著者虬れら高令者の病因は他の多数の䇹年者のそれ之 は些か異なるるのと考㝋ている。

次に血栓，栓塞はどらであるらか，两者の埸合ともに その基礎的疾患の証明がなければならない，文献上では 稀なものであるが，古くは Habermann 17)(1898) が心 内膜炎患者の症例て内耳動脈の程塞老推定L，Escat ${ }^{18)}$ (1906) 6内耳動脈の栓塞が考点られる症例老報告した。 また, Citelli (1926) 他他部位に血管性病桨のあるるの で突登性難聴をきたした6例を挙げ，Saltzman et al 19) (1952) は内耳血管の血柽が原因と推测される3例を報 告, 最近, Kirikae et al 20) (1962) は Buerger 氏病 (大脳動脈開塞性血柽動脈炎) に合併した突発性 難聴の 一例蒙発している，さらに，Hallberg7)(1957) は突 発性難㯖が他の部位の血管障害に先行することがあると 速へ，本症には動脈硬化が病因となることも考えられる

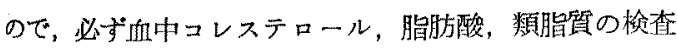
を行ならべさことを強謂した。

以上は血管の器質的障害であるが，それらに刘し血管 彎縮山現在の突発性難聴の病因諭では有力な説となつて いる. その病態については後章に埕るとして，ここでは その発生機䟽のみ述べる。先ず，患者に身心疲労あるい は㣫整的情動变化などの精神身体異常状態が先行，持線
さると，てのために患者蚛異常な緊張状熊を招き（多く

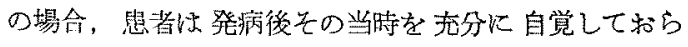

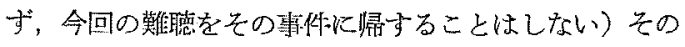
絔果，自律神経平的失調（通常交感神経異常等張）から

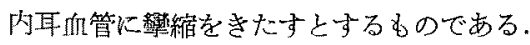

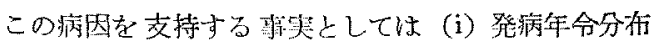
がホルモン失調，白律神絽不安定の年代と一致与ること 10)，(ii）外国に和いてではあるが涨心症（冠動脈整維）

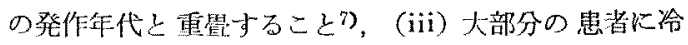
之症，の社せ症，局凝り，頭痛，低血圧などの血管運動 障害の素因が見出されること21)，(iv）発病時期が朝方 覚醒时に多いことはそれが自律神纆变換特期に相当して いること ${ }^{10)} ，(v)$ 難㯰その他の症状が 可逆性のことが 少なくないこと，(vi）アルコール痛做後に 発病するこ とが多いこと，(vii）アレル求ーなど体質的に素因が認 わられることがあること，(viii）治療程駼上血管拉張

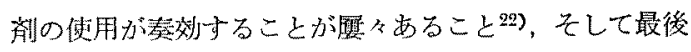

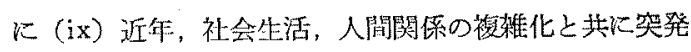

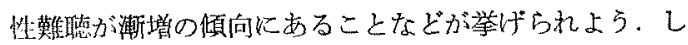
かし，これらの有利な策件が列挙される构らず，この

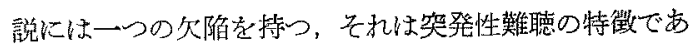
る一生に一回発病といら事实がこれでは説明できないこ とである，即ち，自律神経易失調性体質という素因を狩 らながら，一生涯の頻回の精神的肉体的㣫整誘目に症状 が反復しない理由が明らかにできない点である。

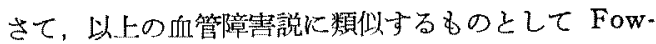
ler ${ }^{6}$ (1950)の sludging 訪がある. 彼は突発性蜼聴の 患者の眼球結膜で血球が結合して流れる状態を観察，こ れは自律神経失調などが原因で起り，最終的には凝集 乙，浮矙，酸素欠乏，毛細血管透過性元進，局所的代謝 不全を生ぜしるる。これが内耳血管にる起り血行障害を 惹起したのが乫発性難聴の原因であるとした。最近，津 崎 ${ }^{23)}$ (1962) はこの赤血球結合性血流を突発性難聴の 6例中 4 例で諰めた上報告しているが，他の文献にはを

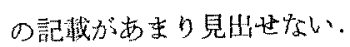

(2) 第8神経神絽药

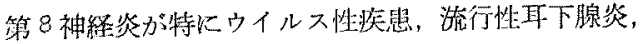
林疹，丹体風疹後に起ることが知られている。. Hilger 24) (1950) 飞よれば第8神纆证脳神経の中で特飞神経炎 に羅息し易いという．上記のウイルス性疾患でるとの主 聇状が前詈に現かれる場合ほ原因も明らかであるが，無 症候性に経過した場合はそれが突発性蜼聴という一症状 を発現したのみに終ることがある(不顕感染)。 
さて，このウイルス性神経炎が乫発性難聴のある割合 の原因となることは確かであるが，比較的多くの比重を それに置く学者はその根拠として（i）軽度の荳発，風 邪，上気道感染，骮莫炎症状の先行することが多い25) 26). (ii) その症状の発現，経過，予後などが顔面神絟 麻㾝 (Bell 型) 飞類似している8) 28). (iii) 流行性に発 病することがある 25) 26) 27)，(iv）血清，䯣液中に抗体 を検出することがある26) 28)（v）一回きりの発病がウ イルス性疾想の免疫形成を思わせる。（vi）聴覚検查に て後迷路性障害の成績が得られることがある。などを指 摘している29).

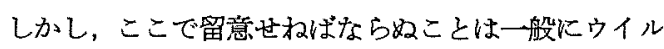
スは神経向性とされるが，必ずしもそうでなく，同時に 血管内皮細胞あるいは血球親和性の型すあることであ る、ウイルス性感染沈上る突発性難聴之思われる内耳の 剖検例を報告した Schuknecht et al ${ }^{16)}$ (1962) によれ ばコルチ器，被蓋，血管条などの各部位が一見無関連に 破壊されて和り，その病態は明らか儿流行性耳下腺炎

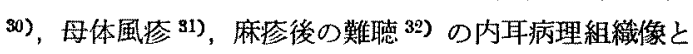
酷似していたという(病態論の項に詳述).

(3) 螖牛内王穴進

これは主としてィニエール病研究学者の見解から派生 した説である。近年，メニエール病の剖検例が陸続と発 裴されるに伴ないその病態は内リンパ圧の充進によると 解釈されるに至つだ3).

その論拠とするところは交感神程の血管運動支配神経 の異常により，内耳血管条毛細血管の透過性が充進し， 内リンパ液が過剩産生される. その結果, 螖牛管内理が 上昇し一次的に内耳液伝音機構を障害する.そしてさら に圧六進状態が持続寸れば二次的にコルチ器はじぬ感覚 終末装置を変性破壊し，難聴を生ぜしめると説明する。

しかし，突発性難聴症例似関する報告からはそれら の典型的メニエール病の病態とは些か異なつた様相が 知られている. 即ち Opheim ${ }^{34)}$ (1951) \& Mygind ${ }^{85)}$ （1947）の突発性難㯖の内リンペ圧元進説より想を得て 突発性難聴の蝸牛管内減王の目的で外側半規管に開空術 を行なつたが，聴力改善の成績は必ずしも良くなく，ま た, Nielsen ${ }^{36)}(1953)$ も同し術式で治療した 2 症例で 1 例は無効といい Svane-Knudsen ${ }^{8}$ （1957 a） の症例で

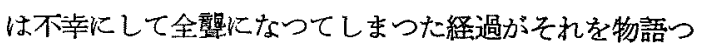
ている. 因みに Opheim ${ }^{34)}(1951)$ の3 手術例中, 内リ ンパ圧六進が認められたのは僅か1例であつたという。

思らにこれらの失敗例は突発性難㯖がそれ以外の種々
の原因です起りらることを無視した適応症例選択の俱り によるもので，実際，突発性難聴のある型には爪床毛細 血管透過性九進の 著明なことが 証明されており（10) 37)， また，あるものでは低音性難聴で恥力䦭值の変動する 例, 複聴, 音の大ささ補充現象の見られる例など所謂 メニエール病初期の病状を呈するものがある。これらで は明らか蝸牛内正充進が推測されるのである。そこで

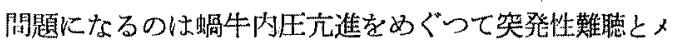
ニエール病との関連であるが，それについては後章隹詳 述する。

（4）中毒性内耳炎

全身の他の部位の感染病巣から内耳にその毒菡による と思われる病変を起す場合である。. Lindsay et al 15) (1950) は上気道感染上り 笑発性難聴の 発病することが あると述べ, Lenhardt ${ }^{38)}$ (1958) は扁桃，雨などの病巣 感染より内リンパ水腫の起りらることを指摘している. また，妊脤中洪症の如きるのによることもある ${ }^{399}$.

（5）急性アレルギー反応

1947 年 Fuchs et al 40) は内耳のアレルギー性浮腯に よりその内圧が上算し難聴が生ずることを報告したが， その後動物過敏症発作を実験的に薏起させ耳介並びに 内耳小血管の血行動態を観察したいくつかの屚究がある 41)-46)，それ《上机ば小血管の 血流速度，血流路に著明 な変化が起り，血栓，栓塞の形成が認められたといら。 それらは重第な例ではあり，そのまま人の耳に類推は でさないであ万らが，上り軽症の変化が起りらることは 考えられることである.

(6)全身疾患

最後に全身疾患に上る笑発性難聴であるか゚，明らかな 原因の認められる例光ば，外傷，先天性梅毒，慢性化澧 性中耳炎, 白血病, 多発性硬化症, 顕性麻疹, 同湦行性 耳下腺炎，脑膜炎などによるすのは突発性に起つたとし ても真の突発性難㯖の篹疇からは除外さるべきと考克 る、しかしながら，実際臨床的立場からその因果関係を 究めるのは困難な場合が多く，㹟義あるいは広義の笑発 性難德とはいらもののその境界は因果関連性の濃淡に基 つく相対的なものである。ただ，云えることは医学診断 学の進歩と共に “原因不明の”といら文字は消去される べき運命にあるものであり，その意味において真の（狭 義の）突発性難聴の領域が縮小されていくことは当然の ことであるう。

さて，以上が 突発性難聴に関する今日までの主な病 因論であるが，例究ば Fowler ${ }^{6)}$ (1950) の自律神経失 
調説, Hallberg 7) (1957) の血管障害説, Van Dishoeck ${ }^{26)}$ (1957 a) のウイルス感染説の如き 各学者はそれそ゚れ自らの見解を強調はしている ものの，彼らに批いてさ各病因に扣く比重は 異なつてす突発性難聴が種々雑多な原因で起る 一症候群であることを羿めている事哭は注目に 洒しよう、事実，個々の症例の間の多彩な臨床 像を単一の機序で説明することは不可能なこと であるが，その症侯群を詳細に観察するときあ る点和いてきわめて類似した共通性るある絽 過が見出されることは驚熯する梳どである。

次にその雑多な疾患より著起される突発性難 㯖の病態を考察してみよう。

[II]突発性難聴の病態論

内耳コルチ器は外界からの機械的振動に反応し，その 生化学的過程を通して感受して次の㥁神猛儿電気的現象 として活動を伝搬する非常に微妙な組織棈造である。こ

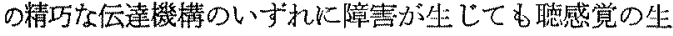
起が坊げられ，所謂内耳珄難㯖が起る。

今艺れらの要素を通覧するに難聴の発現機構は概念的 に形態的, 機能的, 代謝的变化，あるいは縦と梇の变化， 時間的变化などが考えられるが，上り具体的には (i) コ ルチ器の変化，有毛細胞，支持細胞障䇾，被蓋の運動障 害，(ii) 基底膜，ライスネル膜の形態的，物理的変化， (iii) 蟔旋神経節細胞, 線維の变化. (iv) 血管采变化.

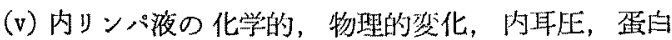

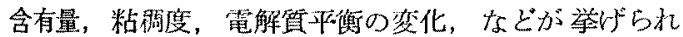
る. 理僃的にはこれらの要素のいずれに病変があつても 正常の㯖覚は起らない，拣た，以下難㯖の病態を論ずる に際し常に記憶せねばならぬことはとれらの変化が物理 的化学的なある次元までは可迹的で方り，次の組織形態 学的次元で不可逆的となる，即ち難聴の病態は二つの段 階に分けられて進行するといらことである63)。

次に些さか詳細個々の問題について教えてみる.

(1) 告ず血管障害であるが，これはいか心も漠然と した衰現であるので間題をどのよらな血行障害がどの部 位化起るかにしばつてみる(因4)。

第一に出血，血栓，柽塞についてどの部位に起りらる 为のか考它てみよう，そのためには人の内耳血管の解剖 学的走行の概略を解説する必要がある.内耳血管系の研 究には Nabeya 64)(1923), Smith 65) 66)(1951, 1954) の 僈れた莱績がある，それらによると人に和ける内耳動脈 の走行は前下小脳動脈から1本の総幹として起始する暘
图 4 内耳政管系。矢印いずれの障害も起りうる (Hilger et al, 1951 より)

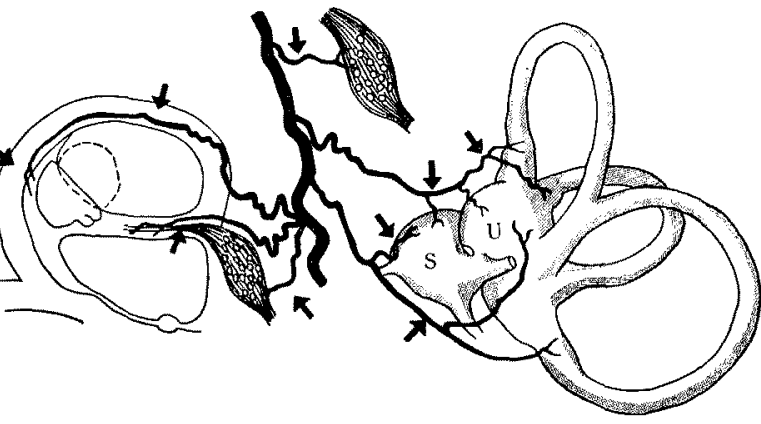

図 5 的耳䵒牛の血管系 (Nabeya, 1923 上り)

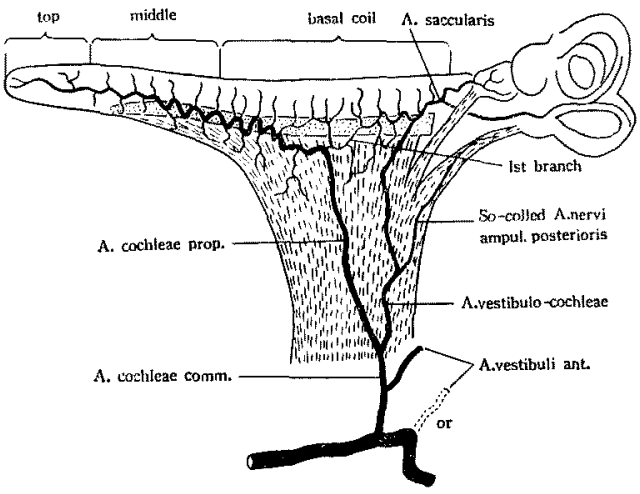

合と2本として起始する場合とがある，前㨋の場合 1 本

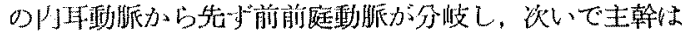

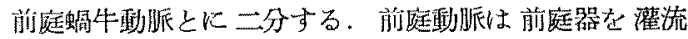

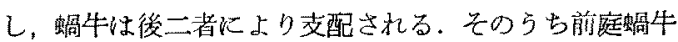
動脈は基磷回転の前半部炕分存し，それより上方即ら基

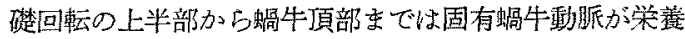
する，後二者の間に经動脈吻合が認められる（図5)。

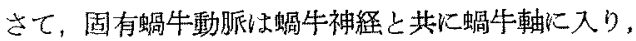
その螺旋状に上行する過程で多くの小枝を蛊牛軸骨壁に 出していく，即ち固有蛤牛動脈はそれぞれの高さでやや 太心第1 枝を出すがそれは固有螖牛動脈の外例を囲もよ らに併走し，数回螺旋状に称しれた後さらに多数の第 2 枝に分かれる。この第 2 枝は蜩牛軸骨壁に入り，直ちに 上下二つの独特のコイル状細動脈を形成する，このらる 上コイル状細動脈は前庭階の上壁骨間腔をや螺旋を描 きなからら放射状に走り，螺旋䩓带，血管条に向から（放

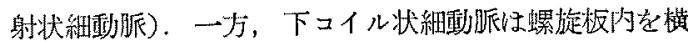

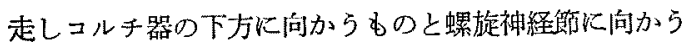


ものとに分伎する。

以上の如く内刵動脈系以基檚回忶前半部に拈いて前庭 蜛牛動脈之固有瀜牛動脈との間に吻合を認める以外すべ て終動脈である，従つてその主幹の障害は直ちに末槄支 配領域の血行障害を意味する。

次に血管障害部位別にやや詳しく考察する， de Kleyn 2)(1944) は彼の21 例の大部分老漠然之中枢血管障蚌 としたが，一側難㯖といら如き任管障整が中枢性に起る としたら他に重篤な随伴症状が見られねばならないであ ろ5. Beichert 47)(1956) 勁頸惟異常に上り頸部交感神 経系を機械的に刺激したと思われる突発性難聴を謘告し たが，この場合椎骨動脈への影響も完全には否定できな いであろう、次に内耳動脈の高さであるが， Hallberg

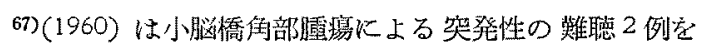
発表，Rasmussen ")(1950) は動脈硬化が内耳動脈沉起 つたと推定し, Mygind ${ }^{62)}$ (1951) む突発性奞䥺は先ず 螖牛軸内の出血に上り生じ次いでそれが迷路に波及し て前庭症状をも誘発するとしている，一方，Dubs $\left.{ }^{65}\right)$ (1956) は内耳動脈の外傷性血程桎に上る笑発性難聴を報 告, Kirikae et al 20)(1962) は Buerger 氏病の突発性 難聴から内耳血管の器望的病变を想定している。最後は 細動脈，毛細血管の部位の血管障害であるが，てれにつ いては次の血管彎縮の貞で記述する。

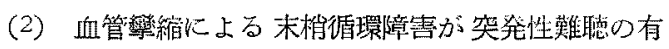

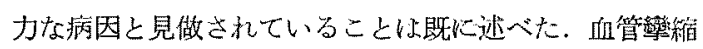
の機枟には神経性要素に上るものととの他の場合とが考 党られる。

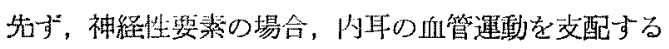
神経任頸部星状神経節から出る交感神経節後線維であ る.この線維は脳底，前下小兴，内耳動脈と動脈に沿つ て走行し，さらに蛤牛軸内涸有蝸牛動脈上共飞入る。 しかし，艺の辺上り次第に之の数を城していき，固有蛤 牛動脈の第 1 枝及び彩 2 枝まで怔見出されるが，前庭階 上壁骨間腔を走行する放射状細勛脈及びその未䊑の螺旋

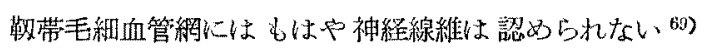
67) 70)（副交感神経系の内耳人の成与は未だ不明である 70)).

これはなにを意味するるので多ららか。一方に执いて 頸部交感神経刺激が細動眽及び毛細血管を収縮させるこ とが觀察されている71)，その事笑をどう解釈したらよい であろうか，血管条の毛細血管は単により中枢側血管の

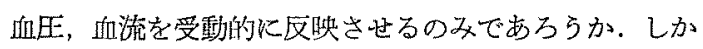
乙，夷際血管条毛絸血管網の血流はコイル状細秒脈中㗢
静脈吻合などの特異な血流調節装置注よりきかめて安定 していることが知られている72).

さて，神経要素が放射状細動脈以下に証明されないと したらその血管運動は体液性要素を考克ねばならない。 即ら，音響刺激など警告信号が視床下部を通じて下垂体 に達するとそれよりの指令で副腎酭質から種々のホルモ ンが分泌される。それらの物質が直接内耳血管作用す ることが推测される。あるいは組織隹生された代謝症 物，血管運動神経の化学伝達物質が影響することも考え られる。

では，それらの物質はどの部位に㗢くのであるらか。 ここで内耳動脈采の壁細胞について形態的にみるに，放 射状細動脈までは弾性線維，可滑筋細胞が認められ，炏 の蠌旋制带でも血管条以外の毛細血管では内内被細胞の他

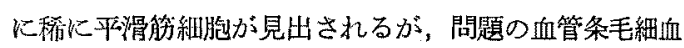
管網は内被細胞のみから成つている（時に血管の外側に いくつかの細胞を譛めることがあるが，平滑算細館かど らか確かめられていないり，この知見からすればホルモ ン臟器あるいは神経終末で游崔した物質が血流で運ばれ 平滑能細胞に達しその活動に影響を与克ることが考党ら れるが，その細胞棈築学的事实からその作用部位は細動 脈までということになる。ただここで興味滐いのは細 動脈から毛細血管に移行する部位に括約装置の存在が推 定されていることである ${ }^{72)}{ }^{73)}$ (形態学的には未たに証明

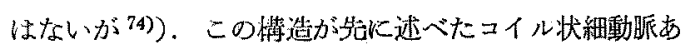
るいは動静脈哆合と其に内耳血行動態を挍動ざせている ことが推測される。

な括，血管条毛細血管運動の体液支配説を支持する いくつ加の基礎实験がある。 即占, Mygind et al ${ }^{76)}$ (1946) 㤃マドレナリン，ヒスタミンを静注し内耳血管 が全身血管と逆の反応態度を示すことから前者が全身血 正变動に対処して内耳血流の恒常性を維持する機能を持 つと推諭したが, Seymour ${ }^{71)}$ (1953), 岡 ${ }^{76)}$ (1959), 菅 野 77)(1963) らはアドレナリンの静注で細動脈, 毛細 血管が収絔することを観察した，一力，Nomura ${ }^{72}$ (1961), Perlman et al 78) (1963) らはアドレナリン, ノルフドレナリンの使用で血圧が一定以上上昇したとさ 血管条の血流速度が增加することを見たが，その毛細血 管の内径の变化は認めない，势た，長倉 ${ }^{79)}(1964)$ は血 管条毛細血管に体液物質の作用することを醉素学的汇証 明している。

以上の如く螖牛の自律神経支配関する知見は今日な 招断片的であり，時に矛盾した成績も得られている。し 
かし，それが神絽性であれ，体液性であれ細動脈の毛細 近管前部を頜縮的に括約するとそれより末梢の毛組血管

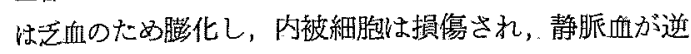
流する。乙とて内被細胞の間がら漓出液が出, 局所性浮

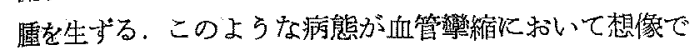
きよう(因6)。

图 6 血管運動神経性障恝とその結果寺す (Hilger, 1950 より)
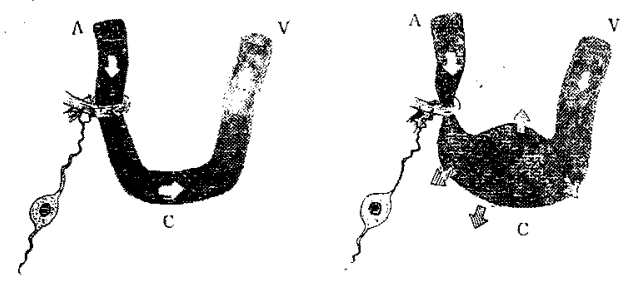

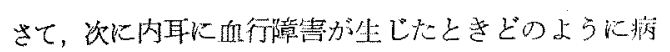

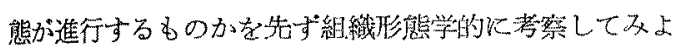
5.この種の研案では内耳動脈圶一特的，あるい恒久

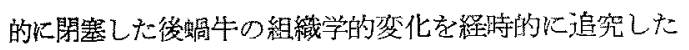
Perlman et al ${ }^{80}$ (1959), Kimura et al ${ }^{81)}$ (1958) の業 綪が秀れている。

それらによれば，内耳動眽閉塞 5 分後では螖牛の有毛 細胞の障害が点状に不規貝潵在性に出現し，特に基礎回 転がより多く障害されたという，しかし一時的閉塞では 損傷は非常に小さく進行性でなからたという，次いで

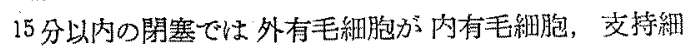
胞よりよりしぱしば障寒されたとしている。これに対 し，恒久的閣塞の所見では先ず 30 分以内で内有毛細胞 か膨化，浮腫の変化を越し，3時間以内に完全に破填さ れた。一方，外有毛緗胞の破壊はやや遅れるが，6時間 以内活と九どの有毛細胞が消失したという，さらに基 底膜，被蓋などが続いて変性した。また，血管条及び螺

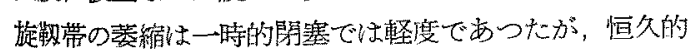

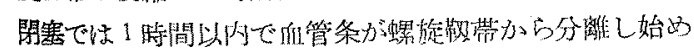

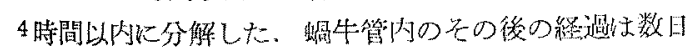
間コルチ器及び血管条からの離䀿細胞成分が内リンパ液 中の特定の部位に擬集することなく浮游して特り，やが て蝸牛管聞筫は線維茅細胞で充買され，一ケ月で閉塞さ

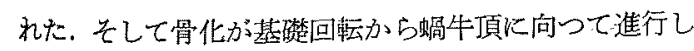
6ケ月で完成した。この経過中で特に注目すべきことは

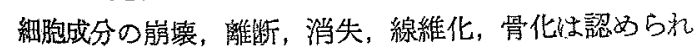
るものの一時的にも恒久的動脈閉塞火も毛細血管の破

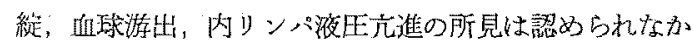
つたということである。

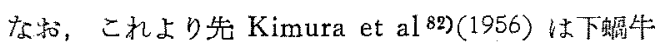
静脈の閉塞による同様の吥究を行なつているが，その場 合にも内リンパ中以出血住認められたが所謂内リンパ水 通の存在を推定させる所見がながのたと述べていること は翻つて笑発性難聴の病態を推測する上飞興味樑い。

次に内耳血流が阳止された場合当然その血流流域では

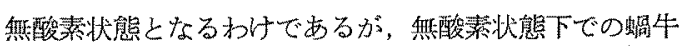
の電気現象を指標しした研究から蝠牛㙨能の変化を推测 してみよら.

先ず，1939年 Hughson ${ }^{83)}$ は血圧低下が 聴力の損 失汇周連あることを暗示したが，後に Gisselsson ${ }^{84}$ (1949) 《血圧が正常の3分の 1 以低下与るとさ眮牛電 位の隇衰の起ることを見，また，酸素欠之による螖牛電

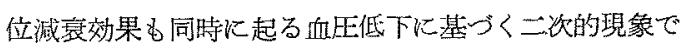

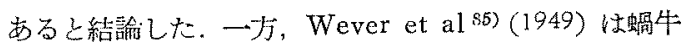

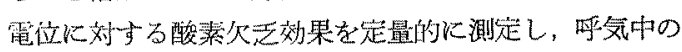

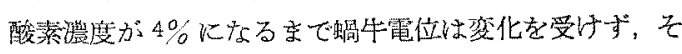
れ以下になると電位は急激に減哀与ることを見出した。 屯た，彼らはこの酸素欠そ状態存反復すると螖牛電位が 累積的に減㚃することを知り，さらに蛸牛電位には酸素 久乏に敏感に減衰する部分と死後もな和数時間保持され る部分の 2 種類あることを見出した。この事実は後年多 くの学者によつて確認されている。

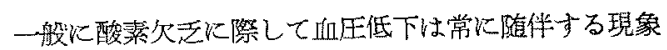
であるが, Bornschein et al ${ }^{86)}$ (1950) は蛹牛を酸素化 した血液で灌流し蚟牛電位の減衰には酸素欠之が一次的 原因であることを主張した。

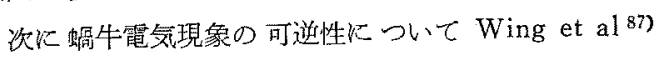
(1952) はネュの蝸牛電位が $3 \%$ の酸素呼気中に 30 分置 かれた後にも完全江恢復することを示し，Gisselsson ${ }^{88)}$ (1954) は螖牛電位は酸素の供給を 30 秒停止すると一畤

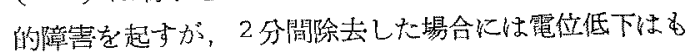
はや不可逆的であつたと速へたた。一j, Fernández ${ }^{80)}$

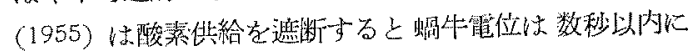

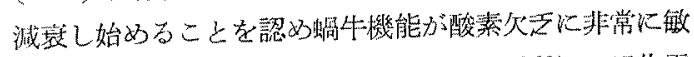
感であると推諭した。东た，Gluick ${ }^{90)}(1958)$ は期物電 位に影留を与える血中へモグロビンの醉素飽和度を指標

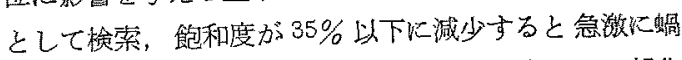
牛電㕸の減衰加起り，先の恢復む部分的であつたと報告 2 .

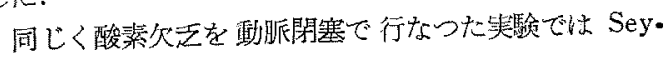


mour et al ${ }^{71)}$ (1953) は内耳動脈を゙開塞したとき最初の 5〜6 分間は蝠牛電位に变化が起らず，次の20 分間に次 第に減衰し，元の值の3分の1に減少したと述べた。さ

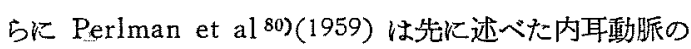
一眭的閉塞後の組織学的研究と同時に血管条の血流及び 電気活動の㚆毁をも検索している。それによると螖牛電 位は内耳動哌閉塞後的 10 秒で咸信し始め，8分以内の 閶塞では完全な恢復が見られるが，30 分以上延長する と恢復は半分以下であるとい5，そして蝸牛電位に恢復 の見られる最大の閉塞期間は60〜65 分であつたと述べ ている.

次に酸素欠乏下の眮牛電位 $(\mathrm{CM})$ と神経活動電位 $\left(N_{1} ， N_{2}\right)$ との関係家みるに1950年 Bornschein et al 91) は酸索除去に拈ける両電位の様態を比較し，後者が 前者よりる酸素欠乏に敏感であることを報告した。さら にFernández ${ }^{89}$ ) 92) (1955, 1959) も蜳牛電位が同一の 無酸索条件下で神絟活動電位より幄くむで維持され，他

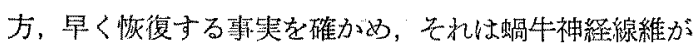
中枢神経系のそれに近い高い代謝率を持ち，一方，有毛 細胞は急速な物理化学的恢復能力を持つことを暗示する としている.最近，Konishi et al \$s)(1961) む前下小脳 動脈を閉塞し蝸牛の諸電気現象 (CM. SP. AP. EP) K 刘する効果を比較検討して同様の結論を得ている。

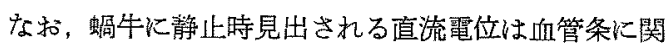
連を持つ電位と見做されており，Békésy ${ }^{04}$ ) (1952) は この電位か酸素欠之时蝸牛霄位之消長を其にすることか ら後者が前者にエネルギ一源として依存することを晅示 L, Gisselsson 95) (1955) む同様の観察を行ならたが, Perlman et al ${ }^{50}$ (1959) は一特的動脈閉塞後の螖牛電

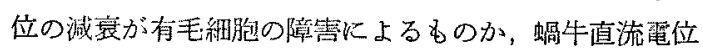
の減衰に結果するものか不明であるといい, Konishi et

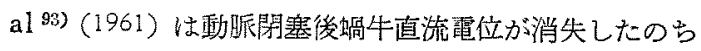
にる螖牛電位の隇京が見られることから前者が後者への 唯一のエネルギー源でないと述べている，さらに最近，

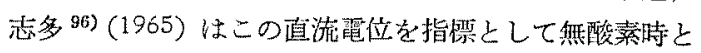

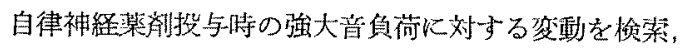
然酸素洔の直流電位の変化が交感神絽緊张状態に類似す ることを報告している。

さて，最後に酸素久乏後の絈織学的帘化については Lawrence et a1 97) (1952) の研究が初めでその結㷊は 先ず支持組胞が破壊し，次いで有毛細胞で，血管条の障 害は重症の例にのみ認められたという．また各回転別で は基礎回轻が族に重篤に損賃されていたといら。これに
対し Falbe-Hansen et al 98) (1958) は急性あるいは埤 延性の酸素欠乏後の海獏及び猫で蝸牛管及び螺旋神経節 に全く变化を認めなからたとし，Fernández et al 02) (1959) \& 3\% 酸素の呼気中に 30 40 分ずつ数回瀑露し た海㺓で内耳に組維学的変化を証明し得なからたと述ぺ ている。な括，Lawrence et al ${ }^{97}$ (1952) の報告で舆 味深いるのは絽織学的に基喽回転で重第な障害が見出さ れているに拘らず，蝸牛電位の減京度は音刺激の各周波 数でほぼ同じであつたという事㝜である。これに類伿の

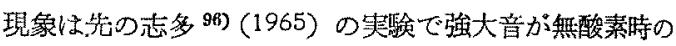
蝸牛直流電位に及ぼす効果恃負荷音の周波数户螖牛回䎐 別の誘導部位に無関係であつたという結果に見られ與味 深い.

さて，以上の無酸素状態下の蝸牛機能の知見を要䄪子 るならば (i) 蝸牛電位の中には酸素欠乏に敏感なるの と血王低下に影㗽されるものとがある ${ }^{85}$ ) 88)（(ii) 呼気 中では 4\% 85)，血中へモグロビン飽和度では3\%以下

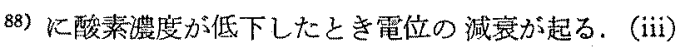
酸素久己状態を反復すると電位の減衰比累積效果が見b

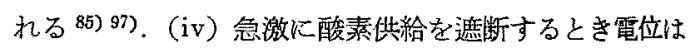
数秒以内に減衰し始める ${ }^{83)}$. (v) 主幹動哌を閉塞した 場合には電位は 10 秒以内に娍裹し，8分以内では完全 恢復が見られるが，約 30〜40 分では部分的にしか恢復

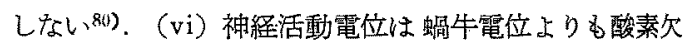

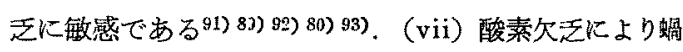

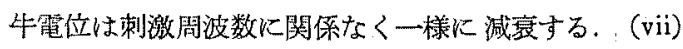
血中酸添濃度が低下すると血管条毛細血管はわずかに拨 張し，血游は停㴖するるど緩徐になる75)44)。(viii) 動 脈の一時的閉塞の場合最低 30 分で内耳に組織学的变化 が起る ${ }^{78)}$. (ix) 青脈閉塞では螖牛電位に変化が諰から れない、99)，(x) 蝸牛電位はそのエネルギー源を血管条 に完全に依存しているわけでない93)。

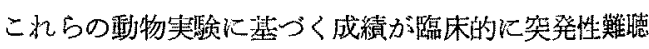

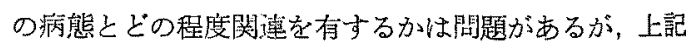
の知見一つ一つを充分に吟昧するとき突発性難㯖の発

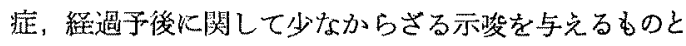
思われる.

さて, Fowler ${ }^{0}$ (1950) は笑発性難埴の発生に自律神 経の失調の病因を強調したが次に自律神経と内耳機能に いて考えてみよう。

自律神経系柱内耳生理的状態を正常に維持与万重要 な役割を演していることは古来知られているとこるであ る，その基礎的研究㠷交感神経刺激，切断術と交感神経 
作用薬物に対する内耳機能の変化の二つの方面から行な われている。

先ず，交感神释刺激による業續では Seymour et al 100)（1951）は頸部交感神経刺激後 10〜20 分で螖牛電位 が3分の 2 から半分に減衰することを観察，それは一部 血管収縮による蝸牛血行障害に上るものでするうと推諭 した.さらに1953年にも同様の結果を確認し，その組

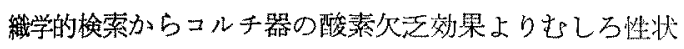
の変化した内リンパ液の分泌滅少によるものであること を述へている。しかし，この知見は Rambo et al 1011 (1953) らによつて追試されたがその效果は見出されな かつたという。な物, 内耳動脈值径ひいては内耳血行量 と䖮牛電位との関保について丸山102) (1956) は蛸牛電 位は内耳血行量が正常のほぼ 3 分の1に減少したときに 初めて変化すると述べ，内耳血行障需による蝸牛電位の 変動はある範围内で血行奖化量の積分として考觉られる と推論している.

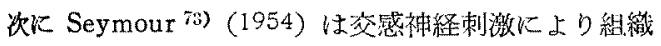

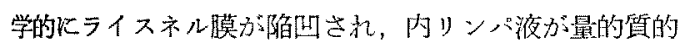
に変化することを観察，それは血管条の血流速度の緩徐 化，毛細血管の透過性六進によると述べた。ささらに交感 神経作用薬物に上る効果に関しては血管条血管を㧴張さ せるとするもの，収䈹を見たもの，血流の增加の及起る とするものなど成績が一定していない，思うにその原因 は内耳自律神経支配の複雑性に帰せられるであるら。同 様の結果は特にメニニール病に対して郘床的に行なわれ る頸部交感神経遮断術の効果が様々であることからも推 測できる。

さて，次に螖牛内压穴進の病態について考穴てみる。 蛊牛内圧の上昇がどのような機祛で起るか未だに推測の

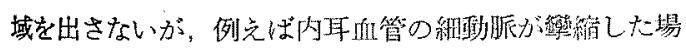
合を仮定する．先ず，乏血のため毛細血管内被細胞が障 害され液成分と共に蛋白成分も内リンパ㵐出してく る.また，一方ではコルチ器からの代謝産物が 蓄磕す

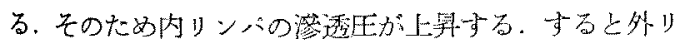
ンパからもライスネル膜を通して液力゙償して来る。 そ の結果媧牛管は異常な搪張を起すこととなる(しかし， この推定炕対しては単なる動脈閉塞の死では内リンパ水 腪は起らないといら報告がある80)81)。恐らく自律神経 系走した他の因子が倠标、ていることと思われる).

では，この蝸牛内圧え進は聴力にどの上らな影響を

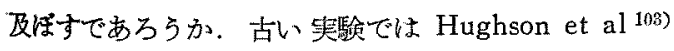
(1933) は異張溶液を静注して脳王及び内耳正を変化さ
せ螖牛電位を指標として聴力との関係を及，内耳仕の上

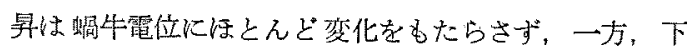
降汢広範国に電位低下を起すことを報告した，次いで Békésy 104) (1942) は人の内耳標本で外リンパ王を上鼠 さ吃ても内耳液伝音機構になんらの影響を与えないこと を实詮した：なた，Lempert et al 105) (1949) はサル

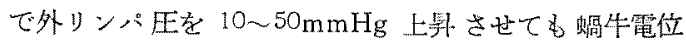
に裂化が見られず，それがコルチ器の感筧細胞の機能を 障害しないとした，一方，坂本 ${ }^{106)}$ (1952) は外りンパ K $10,20 \mathrm{mmHg}$ の陽王 $30,40 \mathrm{mmHg}$ の陰王を加之, 陽圧時に広い, 周波数带域に亘つて水平性の聴力障害を見 出している。これらの实験的結果からみるに一般に内耳

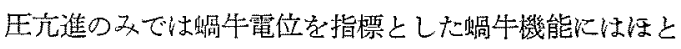
えど影響を与劣ないことが推測される、ただ特に與味樑

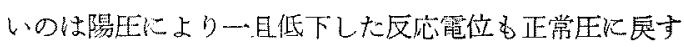
と短时間内に元の值に㞔ることで，これは突発性蜼聴の 可近性を暗示させる，ただし，緣返し加圧したり，強王 を長時間持続さ俯たとさには䉓位は復元しなかつたとい 5.

他方，嚓床的知見はどうであろうか. Hallpike et al 107) (1938)のメニエール病剖検第 1 例以来その病態が内 リン八水垢であることが推定されているが 108)，それに よる聴力障害には種々の考察がある，先ず Mygind 109) (1947) は内リンパ正兄推のため両円空が圧迫され振動 エネルギーの伝達の妨げる結果と推論したが，Lindsay

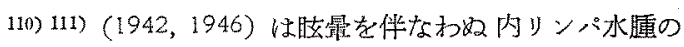
一例ずつを㗇告，その際の難聴の発生機序は球形戰，ラ イスネル腨の需み膨張, さらに前庭鼓室階の容積不均衡 などの機峨的，物理的变化による内耳伝音機棈の障害で 説明できると拈べた。この理諭汇関して最近 Tonndorf 112) (1957) は内耳模型で見事な实験を行なつている. 即 ら内リンパに相当する部位に加压を增加させて行くと基 底膜の最大振幅部位が基璴回転方向に移動することを認

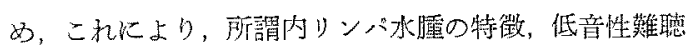

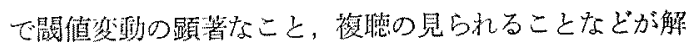

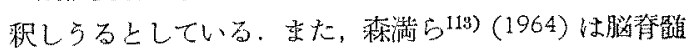

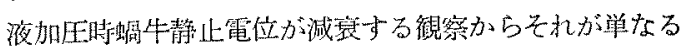
静水圧への影留以外飞も内耳血行動態を障㕩する要素が 多分にあることを述べている。

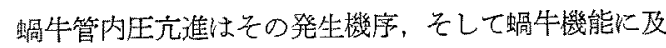
ぼす影響と種タの㥞態が考えられるが，そのいずれにし てもその状態が短期間に復元するならばュルチ器を中心 とする組織棈浩には器質的障寒を遗残することはほとん 
どないものと思かれる。しかし，その病態が持続し不可 逆的段階に及べば当然固定した症候が笺るであろう。

さて，次にウイルス疾患による突発性難聴の病熊を 考察しよう. 先ず，その特徵を Schuknecht et al ${ }^{16)}$ （1962）の報告から要約し，その所見を既述の血行障害 の病態と比较してみる. Schuknecht et al 16) (1962) はウイルス性疾患によると思われる突発性難㯖の 4 内耳 剖検例より次のような知見を得た。即ち，内耳における 最大の病変はコルチ器に見られ，常に螖牛基礎回転が最

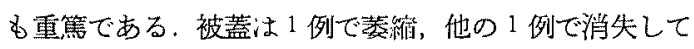
いた，血管条は 3 例で中等度，1例で重篤に委樎してい たが，内リンパ水堙を推定させる所見は全例になかった という。市た，螺旋神絟節細胞の部位々程度はコルチ器 の病変の程度と比例しており、コル器变性の二次的結 果であるうと解釉している.

ではこれらの病理变化は血行障害によるものとどう相 違しているであるらか，既述の内耳動脈閉塞儿上る結果 ではュルチ器，血管条，螺旋神絟節細胞と一連の规則的 变化が進行していることが見出される。そ机に対し，ウ イルス性病変では各蝸牛部位の諸構造が無秩序に全く関 係なく破墩されていることが大きな特改である（例えば ある蝸牛回転で血管条が荒廢していてるそれに区分対応 するコルチ器が保存されていたり，その逆に血管条に障 菅なしでコルチ器が重篤に変性していたりしている). これは実験的動脈閉塞が単に末梢乏血といら単純な要素 で分析されるのに対しウイルス疾患の病態の解釈には複 雑な多因子を考䍐せ极ばなら奴ことを意味しょう。

一般にウイルスの侵入部位には中耳を介して，䯣膜炎 より及び血行性の3 絽路が考党られる。特にウイルス血 症による内耳炎は㧹牛各構造に不規則に分散した障害を 惹起し竞よ5. Lindsay ${ }^{30)}$ (1960) はウイルス性内耳炎 では先ず血管条が初発侵警部位であり，コルチ器や被蓋 はその二次的障害と推論しているが, Schuknecht et al 16)（1962）の障害部位を示与蝸牛地図からは一程沉そう は断定できない上うである。しかし，それらのウイルス 性内耳炎に通じてい方ることはその障害が基恢回転に最 る重应で，蛊牛頂に向かつて軽症となつて行くこと，さ らにその破壊が単なる血行障致, 内リンパ水腫の場合に 比するときわめて急激であるということである、これは ウイルス性疾赖に上る突発性難聴の臨床像之考兄併放せ ることができよう。

次飞, ウイルス性疾患による突発性難㯖汹髄膜炎に 合併したと思われたもののあること酒，顔面神経麻㾇を
併発すること ${ }^{28)}$ ，後迷路性聴覚検查成續が得られること のあること20160061)などから第8神䌊への炎症が原因と する説もまた有力である.

では, ウイルスがこの神経元を侵䪷したときにはどの ような病態が見出されるのであろらか．次化考察してみ よう.しかし，この神絟元に直接発変を生ぜしめること 让困難なので以下は第 8 神綴損傷实験からの類推であ る.

先才゙，組織学的に Schuknecht et al ${ }^{144)}$ (1955) は 第 8 神絽線維を種々の程度に破壊してもコルチ器は正常 に保存される知見から神程元と有毛細胞とは解剖学的に 独立したものであると述べた．これは後に Ruben et al 115) (1962) その他多数の学者によつて確認されてい る.

をた，機能的には古く Dandy 116)（1934）はメニェー 几病患者の第 8 神経切断術を行ない，その大部分を切断 しても聴力閵値にはとえど劦化のないことを報告, Neff et al 117) (1947) は第 8 神経つ部分的選呎的破壊実鈋て 聴力闒値に变動が認如られた場合は常に高音域のみであ つたと述べている。 また，Schuknecht et al 118)(1953) はその領域が受持つ聴力閾值を变化させることなしに特 定部位の螺旋神経節細胞の大部分を破壞できたといい，

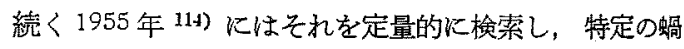
牛区域からの神経線維の $75 \%$ まで損倁してもその対応 周波数の 聴力閵値の上昇が認められなからたとしてい 万.

一方, Kiang et al 119) (1960) は第 8 神絟切断の慢性 奏験で螖牛電位は影響を受けないが，神絽活動電位は的 1ヶ月で消失することを観察した．その後 Fisch et al 120)（1962）洞じ急性叟験で，上記の結果を確証した が，Ruben et al 115) (1962) 《第8 神経切断実数で神 経活動電位の各要素がそれぞれ2 日後，3日後消失す ることを見出し，これに対し蝸牛電位は120時間後でも 正常と变化がなかつたといら，また，本邦に括いても片 桐ら 121) (1964) は Ruben et al 115) (1962) と添潘同様 の成續を挠表している.

さて，これらの報告からみると有毛細胞は機能的にも 第8神絓元から独立しているといえよう，しかしなが ら，既に述べたようにウイルスは神経幹のみを障害する むのでない，また，仮に神経幹が初発侵翼部位であると してもそれより毒素作用が内耳に波及することも考光ら れるし，また，局所に浮腫，䐦張の炎症病変があれ杜必 ず血行障書を併ないそれが内耶障害を招来することも推 


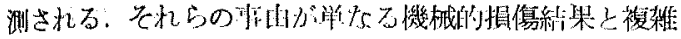

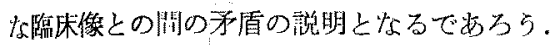

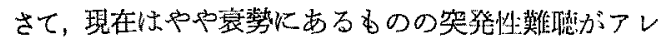
ルギーあるいは病巣感染炕よつて生ずるとする考克る完 全には否定できないであろう，特に実験的に過敏症ある い㤝スタミン発作を起させた場合，全身特に心，肺， 胿，繁などの細小血管に見られる病態は今まで述べてき たそれとは比校にならない汪ど重篤なるのである。

この種の実験を内耳血管で行なつた初期の実験には Mygind et al 75) (1946) の業續がある. 彼らはヒスタ ミン, フドレナリン注射後, 内耳血管の変化を組織学的 に検索した。これに対し Weille et al 42)（1954）は過

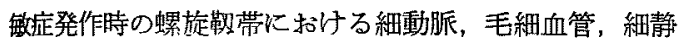
脈の各壁及び血流細胞成分の变化を顕徽鏡的に直視し， 細動脈の收縮, 細静脈の㹡張, 白血球の血管壁膠着, 毛 細血管及び紐静脈からの血球の漏出，游走白色血桎及び 挰塞による毛細血管血流遮断などを観察した，次いで Irwin et al ${ }^{43}$ (1955) る同様の知見を他動物でも観察 報告した。 さらに最近, Terayama et al 46) (1964) は アレルギー発作後の海猽の内耳を広汎江検絮し，主な変

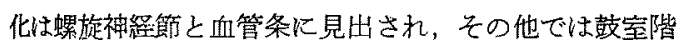
の出血及びュルチ器の破買を認めている，去して特に血 管条に和ける多彩な変化は中毒性，ウイルス性内耳炎に よるすの，静脈閉塞，無酸素状態下のそれなどに類似し

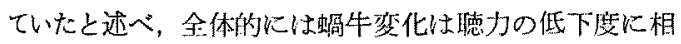
応していたと結論している。

結局，動物のこれらの小而管に际駼的に惹起せしめた 澈しい病態が人のアレルギー疾急ひいてはィニエール病 及び笑発性難㯖のある型のもので实際に生ずるものかど

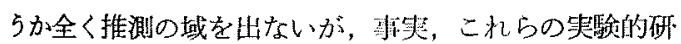
究の知見恃充分に臨床上の問題に類推性を持ち與味ある すのと思るれる．例えば過敏症発作後, 動物が死亡しな からたときには多くの栓塞は流れ去つたが，ある血柽形 成は消失しなからたといら如き病態は突発性難聴の予後 を示唆すると考兄ることができよう（図7）.

さて，最後に突発性難聴の症候学上りその病熊を推察 してみよう。

まず，㯖力像からみるに，突発性難聴の大多数が内耳 に限定された障害であることが添淁明らかにされている 琴在，その聴力像柱内耳病態の投影と考えることができ 上5. 突発性難聴の聴力像には種々の型があることが知 られているが，その大部分は全音域障害型と高音域障害 型とに大別される，そしてその予後は一般的に前者に良

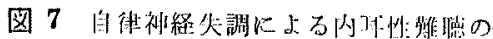
登性機序とその研栄手段

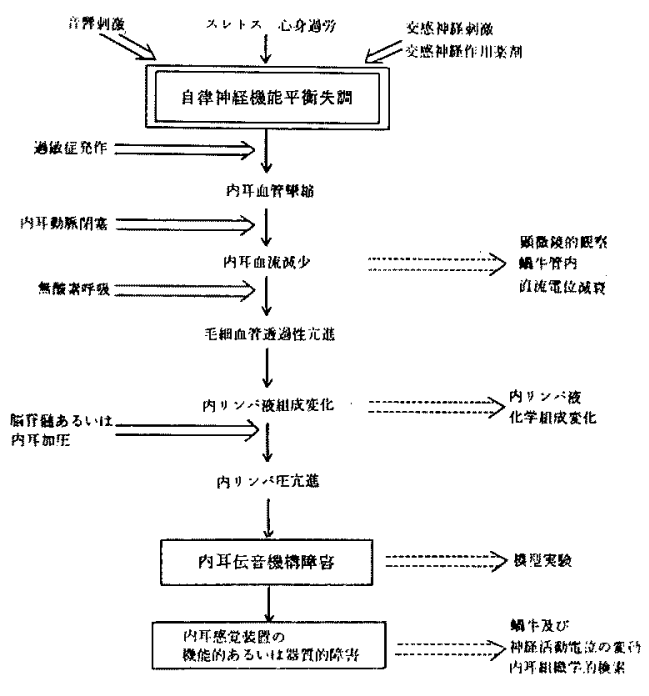

く，後者に忢いという成績が報告されている120)．

先ず，全音域障羖型であるが，これについては比較的 主要血管のあるいは広沉な蝸牛細動脈の 㐿縮を考光た い.その結果蝸牛管内は综注全域に亘りリンパ水腫の状 態になるるのと思われる、いわばこの聴力像は Lindsay 110) 111) (1942, 1946), Williams et al 123) (1950) Бの い5内リンパ水脜の投射と考充られる. 従つてこの種の 型は人ニエール病の蝸牛型ともい党上う。一般飞全音域 䧛害型は完全恢復することがある。少くとも低音域の恢

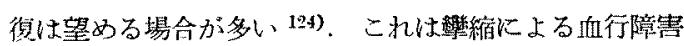
が比較的短時間で解消し，水腫状㦔が聴覚機構になんら の器質的障害を残さずに消退したと解すべきであるう． しかし長時間血行遮断が続くと組織には不可逆性变化を きたす，その損傷の程度は閉塞部位の大小，程度の軽 重, 時間の長短, さらに聴器組織側の感受性などの要素 に上り左右される。

多くの臨床峴察からは全音域障害型の恢復過程は低音 域から始まり完全化正常飞戾るか，高音漸傾あるいは急 墜障害を後遺するという 124) 125)。この高音域障害が器質 的変化と見做すことがでさよう，蝸牛管全体炕均等飞压 穴進がありとれが消退した後，何故高音域のみに障害が 遗残するのであろうか.

その理由は蝸牛各回転の血管分布からは説明し難い 上らに思斿れる。というのは既述の如く, 基礎回転に おいて前庭螎牛動脈と固有蛹牛動脈との間に吻合があ 


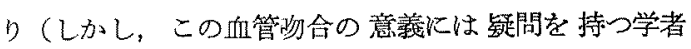

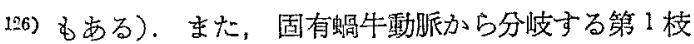
の数も基礎回檕任ど多(64)、では，この高音域の易障害 性，不可逆性はどら説明されるのであろらか.一般に各 回転で見出されれている特街の相違には（i）基底膜の厚 さ，幅及び物理学的振動特性 ${ }^{128)}$ ，(ii）放射状細動脈の 数，螺旋鞄带及び血管条毦細们管絧棈造の複雑性 44) 64), (iii) 求心性及び遠心性䋩維終末の形態学的状態128) 129，

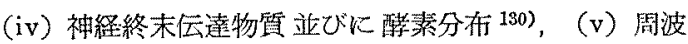
数分析機能を持つ聴神絟線維分布密度 ${ }^{131)}$ な゙が举げら れる。

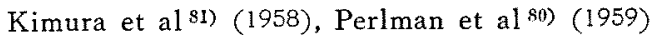
が内耳動脈閉塞実験で, Lindsay ${ }^{\text {00) }}$ (1950), Schuknecht et al 16) (1962) がウイルス性内耳炎の 剖检標本で 其に基礎回転ほど障害が著明であつたと報告した事棒い 特にその部位の特巽な抵抗脆弱性を勗示するが，著者仿 螖牛基底膜上の各周波数応答線維の分布並びに数の比率 からも考光られると思5．即ち，一般に高音城反応線維 は基礎回転に多く分布し，低音域反忘線維は全休的に分 布する。そして前者は数の割合からもはるかに少ない。

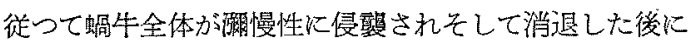
残る高意域障害型は聴神経の各周波数特舅線維の冗長度 の反映と見ることができないであるらか，

次に，も5一-の高音域障害型心病態上ざら解釉でき るであろらか，先ず，上記の如き血行障害—内リンパ 水㖶の終焻状態であるとも見られる。しかし，発病初期 から高音域にの文障害が認るられ容易に恢復しない型が ある。これに閔しては血行障害の重篤なものとするより むしろ病因を他にして例えばウイルス感染の如き神経要

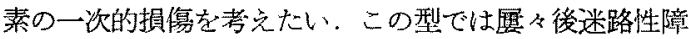
害が聴覚榆查で証明されるので他の型とは鑑別でさる。 この型の病態の激烈な例では全音域に障害があり，全繁 となるものがある。いずれにしてもこの型では感覚神絽 要素の損傷のため多くは不可逆的であり恢復し難い、乙 かし，突発性難聴の中でこの型の占好製恰は比転的少 ないものと思呩れる。

この他，突発性難聴には種々の聴力像が見られるが， それらには経時的に変動する例もあるのでその聴力型の 判定は常に检查時点を考慮してなされねばならない，登 病後か在り释過した聴力は必ずしも発病時の病態を示し てはおらず， また，2回以上の湘定で比較する場合でる その間隔が長ければその中間の㾍熊变邆は物語れない。 徒つて正しい病熊の把提は短い,間隔で繰返された众㚗成
图 8 癸発性難㯖に関する著者の見解

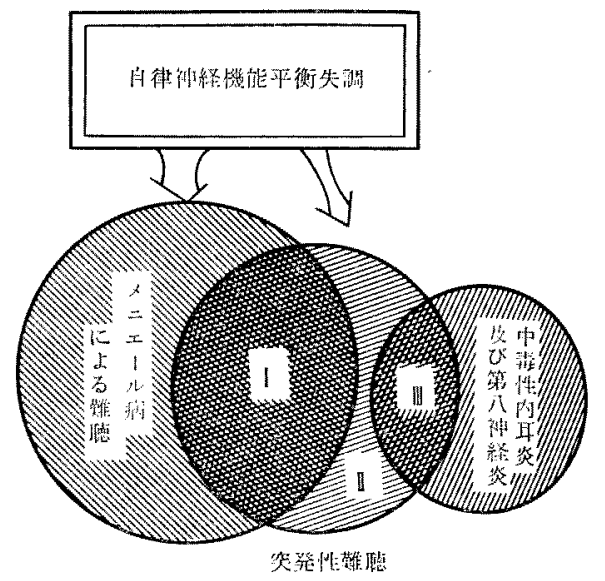

綪の推移の判定によつてのみ可能であるということがで き5.

最後に著者の考按による突発性難聴の概念を図8に示

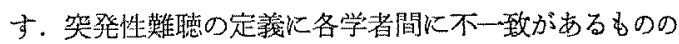
著者は笑発怪難聴の少なからざる数がメニエール病と同 一の籍瞦に属するものと考える。突発性難㯖各何故一生 一度しか起らないかは不明であるが，著者は主として病 变が蜛牛に限られ，一度きりの発病の型が広義のメ二エ 一ル病にあつてもよいと考光る。といらのはこの両突想 の病因に自律神経機能失調といら共通の大きな背景が想 像されるからである。

\section{(II) 本症例関学名考察}

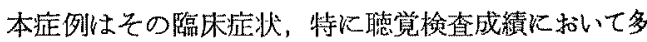
くの與味ある点を示した，以下，去れらにつ、て考察 加党てみたい.

(1) 純音聴力検沓:

本症例虫発病後第3 日目に外来を訪九，初馀時㯖力模 查で典型的な谷型聴力㗹を示した。 それは $1000 \mathrm{cps}$ 底とするほぼ效的な深いdipであつた。一般に突発 性難㯖の恥力像は完全警をを除けば高音域障害型と全音域 哑青型が多く所謂谷型として報告されている数は少ない

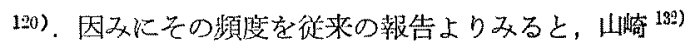

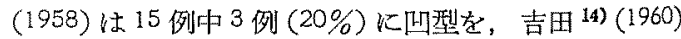

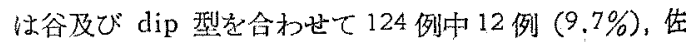
藤ら 133)(1957) は5 例中3例（60\%）が谷型であつたと 報告, 切替ら ${ }^{13)}$ 生1960年に 19 例中谷型 3 例 (16\%)

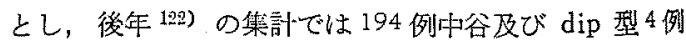
（2\%）を見出している，事た，外国の文献では Lindsay 
et al ${ }^{15)}$ (1950) は 16 例中 dip 型3 例 (19\%) 党, Hallberg ${ }^{48)}$ (1957) は 89 例の血管性障害が病因と思放机る もののうち4.5\%记 dip 型を認めたと述べている.こ れらの報告数の相違はその基準の不一致によることも考 党られるが，本症例の如き典型的 dip 型は上り稀と思 われる。なお，本疾患に乱ける谷型頻度を一般感音性難 聴と比烄してみるに切替ら ${ }^{134)}$ (1950) は 247 例中 19 例 $(7.7 \%)$ 飞谷型を見，山崎 136 (1959) は552耳中 dip 型54耳 $(9.8 \%)$ 谷型 23 耳 $(4.2 \%)$ と報告している.

次に，本症例江類似した聴力像の症例を捗猫してみる と, Hallberg 4s) (1957) はやや㳿傾の谷型了例を記載, 大和田ら ${ }^{186)}$ (1959) は特に 1000 cps が恢復の遅れた谷 型急性難㯖の 2 例を報告し，中音域が特に障害を受け易 い型す確か存在するのではないかと推論している。 た，山㱦 ${ }^{137}$ ) (1958) は 500 800 cps を底とする变型の

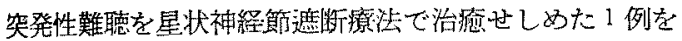
述へ，松本 ${ }^{138)}$ (1959) はその2 例中1例反 $1000 \mathrm{cps}$ が 底の谷型のものを報告しているが，後者は著者らの症例 にきわめて類似している。 また，Walander et al 59) （1960）の報告した症例 2 及び4も1000eps 的心之し た谷型で本症例化似ているとい克よう，なお，同し谷型 でもその底の部位は各報告例で多少異なる、最近武末 139) (1965) は各種の dip 型聴力を有する感音性難聴例 の122耳について統計的観察を行ない，1000 cps 以下で は $500 \mathrm{cps}$ 飞 dip 型聴力定例の多いことを見出してい る。また，これは所謂騒音性突発性難聴ではするが，立

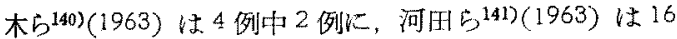

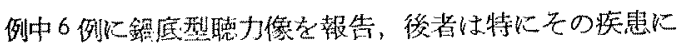
鋸底や水平型嚾㯖の多いことを指摘している。

さて，これらの谷型笑発性難德に見られる大きな特徽 は气の著しい恢復性である．Hallberg ${ }^{48)}$ (1957) が典 型的 $\mathrm{C}_{4} \operatorname{dip}$ が 2 週閒以内に恢復した例を述べているの

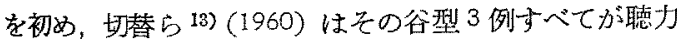
改善をみ心といい，佐藤ら 139) (1957) の2 例大和田ら 130) (1959) の 2 例，松本 ${ }^{198)}$ (1959) の 1 例, Walander et al 52) (1960) の2 例などすべて 正常に近く恢復して いる. 著者らの症例も約 2 週間で正常聴力を示与に至つ ているが，これらの事実は中音域方特汇陆整される乫発

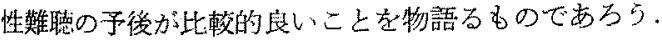

また，大和田ら130)(1959）注笑発性難聴の谷型について 水平型難聴の初症時之完全恢復時の從来の镇察のみでは その恢復過程比 谷型を示す段掯が少なからずあるのが 見逃がされてしまつているのではないがと考察してい
る，谷型が水平型比至る途中段階であるか，またとれよ りの恢復段階を示吉ものかは別としても，方る中音域の 特定周波数部位において最も早く闎值が上昇し，最も痋 く恢復し，その雨辺があたか子扇の開閉を見るが如く変 遥する聴力像の推移のあることはきわめて與味深い，

次に本疾渑に和けるレクリュートメント現象につい て考察する。この現象を本疾患で初邓て 険討したのは Rasmussen 3) (1949) で6 例炕行ない，4 例时明らが 陰性，1 例小除性傾问，1 例は陽性とこの現象の成立乙 難いことを示した，また，Hallberg 7) (1956) は聴力の 残存するすべての症例煌性を譛め, 病因の内耳性を主 張したが, Svane-Knudsen ${ }^{8)}$ (1957) は9 例中僅か 1 例 のみに陽性であることを見，中毒性あるいは感染による 第 8 神経炎病因々想定, van Dishoeck ${ }^{26)}$ (1957) は 44 例中 26 例に陽性，18 例に除性であることから内耳性 以外飞る後迷路性難㯖のあることを推測した。ささらに，

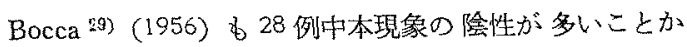
ら第 8 神経炎を病因としている。

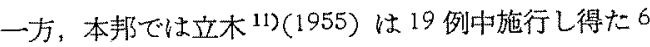

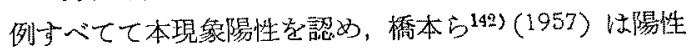
例が多いが检查不能のことの少くないことを指摘，中村 ら 12) (1959) は19 例中施行できた 7 例中 5 例に陽性，1 例に陰性であつたといい，吉田ら ${ }^{14)}$ (1960) は13 例中 11 例飞検查でき8 例が陽性，3例が除性で方つたとい 5.ささらK, 南立 ${ }^{143)}(1961)$ 《 56 例中施行可能の 8 例 の5ち6 例に陽性，2例に陰性であつたと述べ，切替ら

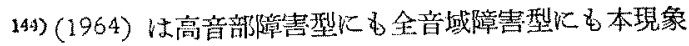
が高率に出現することが証明されたとしている。な格， 既述の谷型難㯖の大和田ら ${ }^{136)}(1959)$ の 2 (例，松本 ${ }^{138)}$ (1959) の1例, Walander et al 52) (1960) の1 例は 共に本現象陽性であつた。

レクリユートメント現象の現在の臨床的意義はそれが 内耳有毛細胞の障害で現われる症状であり，それに後迷 路障害が随伴しても陽性となることがあるが，乙かし後 者の障害が大なるときは内耳障害があつてる隠蔽されて 陰性となることがあるといわ机る。この事実よりみれば

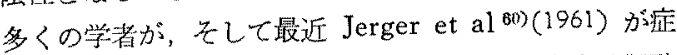
例の詳細な聴賞検索から推諭している如く，突発性難聴 の病变には内耳性と後迷路性の二種類あるとするのが妥 当であ万う。そして上述の本現象の陽陰性の此济住両病 変のそ机音暗示していると子解积されよう，著者らの症 例でる典型的レクリニートィント現象が見られ，㯖力の 恢復と共に消失した。発病初期に $250,1000,4000 \mathrm{cps}$ に 
衿奶られたことは Harbert et al 61)(1964) の述べてい る如く，有毛細胞のやや濑慢性障害寺示するのと思われ る.

さて, 内耳蝸牛に病変があつたり, 疲労現象の認めら れるとき，純音が本来の澄んだ音として聞かれなからた り，言葉の語音に金属性の音色を帯びたりすることが知 られている。このような現象で最む屡々認められる型は 同一の純音が兩耳で異なつたピツチに聞点る不調和性両 耳複聴である，著者らの症例でも初猃时よりこの現象が 顕著比認められた。

複聴の病因については古くは聴覚中枢路の障害が推定 されていたが, Shambaugh 145) 147) $(1923,1935,1940)$ は多数の難聴正例の検索からそれが内耳の著明な急性難 聴に見出されることが多いことからとの病変部位を蝸牛 のコルチ器の振動要素と結論した. その後, Lindsay et al 110) 111) (1942, 1946) 及び Williams et al 123) (1950) は所謂内リンパ水隀症例で本現象の認められることを報 告. Eby et al 148)(1951) は内内取性難恥 27 例中 23 例似 本現象が見出されるのに対し，神絽難聴では16 例中唯 1 例であつたとし Tonndorf 112)(1957) は蝸牛模型実験 で内リンパ圧上昇と共に複聴の出現することを実証，さ らに典型的 1 例を追加した。ささらに最近 Harbert et al 61) (1964)はメニエール病の如き広沉な有毛細胞障富に 複聴が伴なわれると述べ，Albers ${ }^{149)}$ (1965) も発生部 位を内耳と想定している。

次に本症例では聴力検査に際し純音の性貿が失なわ れ，1000 cps が $800 \mathrm{cps}$ に近似した音に聞党ると訴えた が，特に與味深いのは喼耳に捣けるピッチの移動の方向 である.こ机ついて Shambaugh 14(1) 1+7) $(1935,1940)$ の症例は僅か 2 例を除いてすべて上方に移動を示し， Hilger 24) (1950) も患耳でのピッチ感覚の上杽を指摘, Albers ${ }^{149)}$ (1965) 6障㕩耳で一般に高い音として聞え ると述べている。これに対し内耳疲労現象による複聴の 研究ではその移動の方向に一定の成績が得られていない 150) 151). 即ち，Békésy ${ }^{152)}$ (1960) は800cps で疲学を生 ぜしめるとその上方では上り上方へ，下方ではより下方 へと $800 \mathrm{cps}$ を中心に対称性に移動与るといい，Rüedi

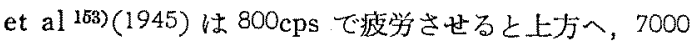
cps では下方へ，4000cps の場合には不变であつたと述 べ, Davis et al 154) (1950) は 120dB の純音あるいは ノイズを 30 分乃至 1 時間負荷した 後著明なピツチの上 万への移動を维察している. Davis et al 154) (1950) は この上方移動現象を蝸牛回枟基底膜上の疲労領域とその
振動様式との関係から理諭的に説明しているが，一方， De Mare ${ }^{155)}$ (1948) は䧗床絽験からピッチの移動の方 问は最も障害された基底膜の部位から障害のないあるい は少ない領域へ移動するといら原則を発表した。この原 理を本症例に応用するならばそのピツチの下方への移動 は $1000 \mathrm{cps}$ より上方に比べり下方で障害が軽度であ つたことを暗示しょう。

そのいずれにせよ本現象は我々も屡々ムニエール病な どの急性期に 経験するところである。また多くの学者 24） 148） 149)がレクリニートメント現象之密接な相関を指 摘しており，複聴の見られる症例は比較的予後が良く， 聴力改善と共に複㯖が消失することも與味深い，恐らく 内リンパ死の上昇に伴なら基底膜の弾性变化，蓋膜の振 動様式の变動などの機能的障害による現象で，その原因 の消退と共に容易仙恢復するものと思われる。

次に自記オージオメトリーの成績では各種検查に上り 確実に内耳性障害を示するのは認められなからた，最近 Jerger et al 60) (1961), Harbert et al ${ }^{61)}$ (1964) は突 発性難㜇症例飞ついて本検查法で内耳性と後迷路性障害 の爁別を述べているが，本症例の検査成績ではいくぶえ 前者を瞕示するに止まつた。

(2) 方向感榆查

著者らの行なら方向感検査法といらのは同一音源加ら のバンドノイズを一定間隔で切断し，それを2つのマ1 クロホンより誘導，レシーバーでそれぞれの音を両耳に 与克る方法である。この方法で 2 つ集音マイクロホン 間の距離を任意に変化させる々两耳間にそれ机応した時 間差が坐じ音像が移動するのである。この場合，著者ら はこの音像が正中からずれたことを認知できる最小時間 差を“音像移動弁別間值”として臨床的に応用してい る. その正常値は $2 \mathrm{~cm}$ 以内とされているが 156)，本症 例では患側病的㧤大を示していた。

一般に音像成立機転は理論的火次のように考えられて いる、即ち，ある一定の時間差を持つた同一音が両耳儿 与えられると雨耳の螖牛回転上の対称の部位でその時間 差を投影した興雷が生じ、インパルスが起る，その発生 特䦚差が中枢の両耳相関照合蔆置（仮説）に伝点られ， そこで分析され方向覚が形成ざるのである．この場 合，この音像成立の最も重要な前提条件として両耳蛹牛

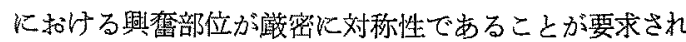
る、換言すれば两耳上りのインパルスが中枢て融合する ためには蝸牛回転の與礬部位の一致が必要である(この

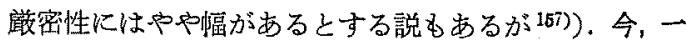


側の蝸牛回転の一部に限局性の変化があるとすると（短 音の方向感に関する神経情報は主に蝸牛の基礎回転から

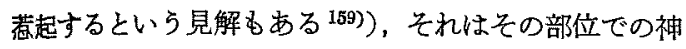
経インパルスの発生様式を障害するであるう。白結果 は中枢の㫟合機構には相互相関度の小さい情報しか送ら れず，その側の方向感が不正確になることが推測され ๖.

一方，臨床的には Sanchez-Longo et al 159) 160)(1957, 1958）は側頭葉睡痗患者で反対側の方向感の障害を報告 L, Matzker 161) (1959) も万向感障害俚脳幹から大脑 皮質までの病変で起り得るが，その障害側は聴覚伝導路 交叉以前では病变と同側，以後では反対側になると結諭 している．著者らの症例ではこの推論からみれば，交攴 以前の病変と考光られ，他の症時と合わせ考光机ば内耳 生障害が最も妥当であろう。な抗，方向感障害も聴力改 善と共比正常泟復している.

(3) 語言聴力検査

本症例の普通語音検䍒ではその最高明膫度成績におい ては注正常值を示し，且つ左右差を汪と儿ど認めなから た、普通語音㯖力の最高明瞙度がはたして内耳性難聴で 低下するであるらか。特に本症例の如き可逆性を示す一 過性急性難㯖で障害されるであるらかの問題はき放めて 興味深い。

一般に突発性難㯖の患者は他人の言葉が響く，つ昰

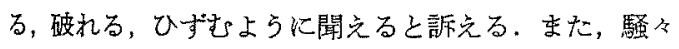
しく聞克すぎたり，逆に響きが全くなくなつたりすると

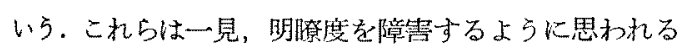
が, 病変が们耳儿限局され，後迷路が健全の場合，特に 本疾患の大部分を占める若年者で怯多少の語音感の变化 はその大きな元長度によつて代償され，奏際には检荃成 績を低下させないと推測される。

逆に, 次の周波数歪, 切断, 分剖語音検查での患耳に おける明膫度の低下はそれらの検査自体主に後迷路性障

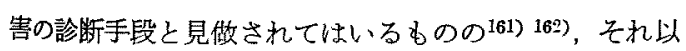
前似内耳分析機能の侓常が検查成績判定の前提条件とな ることを物語るものであらう。これらの企語明瞭度の障 害孔德力改善, 複德及びレクリユートメント現象の消失 之共に正常に恢復した。

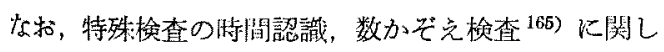
ては未だ多くの㭘査成績を持たず，それよりの結諭を得 ることは售早と思われるので参考までに記載したが，聴 覚機能に括ける時間的因子は第三の要素とむ見ることが でき，現在著者らもそれを検索中でいくつかの興味する
知見を得ている。

（4）本症例の病態発生機模

さて，最後に本症例における病態の発生機構について 総括的に考察してみる.

(i) 病因については心身の遄学に上る自律神経失調 が内耳血管運動障害を招来したと考光る。

発病前の鄞務状況，早朝の発症，冷克症などの体質等 がこれを支持する、入院後自律神程機能検查正常篹囲之 いら所見についてはその失調状態は一過性の短時間のも のであり，数日を緑た後では正常に復していたと解釈で きないであるうか。

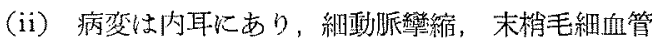
透過性え進に上る所謂内リンパ水殹と考号る。

内耳主に螖牛謨迷路が侵熟部位であることは多くの症 状，聴覚榆育成績が暗示している，血管攀縮隹推測の域 を出ない，あるいは赤血球結合性血流であつたか子知れ ない 104)、いずれ炕してもそれより末松に而が起り，

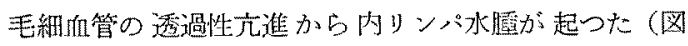

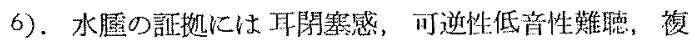
聴、レクリユートメント現象などが挙げられる。

（iii）病変部位恃螖牛回忶 $1000 \mathrm{cps}$ （蛤牛基部より $20 \mathrm{~mm}$ 附近）を中心病態は内リンパ水賈による基 底膜，蓋膜の渾動障赛を主に考光る。

$1000 \mathrm{cps}$ を中心病変の拡大した理由は不明である。

しかし，文献上，特に中音域が障䉥され易い䍿が少なか らず見出される，細動脈は勿論，血管条毛細血管には吻 合があるが，局所性分流が主で機能的には終怔脤である

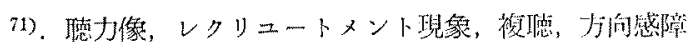

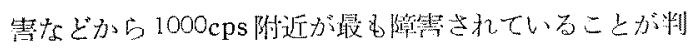
る。局所性飞細䡃脈變維の起ることは自律神経失調上い

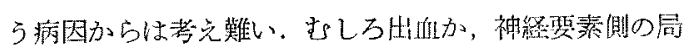
所的抵抗性 (几長度) の相違省学たい。

病態は運動样式の変化など機械的障害までが考点られ る(細胞代謝にまで買常が進行しても可逆性の可能性は

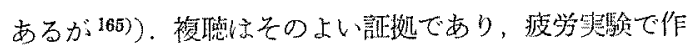

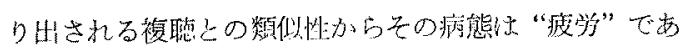
るとも云充る。

(iv) 可道性については病奖の進行と軽快との逆転の 時点が重要である，その時点が扎管篎縮か，内リンパ日E 穴進か，物質代謝障害加，感觉細胞落縮か，神経線維変 性かが問題である。本症例でけ内リソ゚正光進とそれに よる渾動障害の段階で進行が止まり，好転したものと考 亲万。 
（v）治滰に関して本症例は入院と共に代謝促進郕， 血管拡張成，神経栄㙋剂などを投与して症状の軽快をみ た.

近年，自然治鼡症例の報告が集程されるにつれ治療の 要否が問題とされているが，著者らは低・中音域におけ る難㯖は時に治療を行なわずとも自然恢復することは認 めるにしても，病因病態が注济明らかにされた今日，生 体の修復機転に対してそれを助長すべく皘極的な治療が 行なわ机るべきと考える.

その治療方針はその病驡上り推して（i）自律神経失 調、ひいては血管機能不全を惹起せしぬている要素を除 去する，環摬因子，体質素因の改善など，（ii）血管神 経機能失調を皘極的に恢復せしめる。交感神経遮断術及

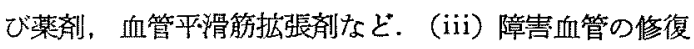
を促進, 助長する，血管壁強化ビタミン剂，甲状腺，ス テロイド剤など.（iv）物質代謝異常の正常化を促進す る. 各種ビタミンATP.など，が有効と思われる。

特に著者は本疾患の治療に沶いて発病以後の環境改善 の必要性を強調したい。即ち，不幸にして発病をみた ら直ちに就業を䈌禁し，可及的に入院加療を行なわせ る. 患者は単なる難㯖のみが愁訴なので発病後も従来の 騒音環境の中で複雑な業務にたらささわつたりし勝ちであ る、しかし，それほど自覚しない難聴が業務遂行上非常 な障害となり濄度の緊張を強いられ，神経はより多く疲 労する、また，突然難聴という身体障害を持つ患者が遠 路外来治療に連日通うのも同様の意味で問題があると思 われる，往つて発病後はしかるべき闌静な環境下で疾 病，業務について澡く苦悩することなく生活するのが本 疾患の恢復に最も大切なことではなからうか.この点に ついて最近の後藤ら ${ }^{166)}$ (1963) の無音と聴器の研究は大

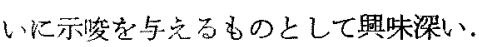

\section{第 IV 章 結 語}

55 才の男子で突発性に中音域に 典型的谷型難聴を示 した一例を報告した。

笑発性難㯖仗比較的若年の健常㨋に突然発症する点で きわめて特異である。一般に感音珄難㯖は緩徐であるが 常に進行性に增恶するのが常識であるのに本疾腎は著し く対照的である。

それい前者が一次的に感音神絽要素が障害されるに対 し，後都け先ず和管障害が起り次の段階で感音系障害が 綕発することから納得されるであるう。

そこで著者は老人性難聴を代表とする一般感盖性難衈 に対し，若年者に笑発性汇発症寸る内耳性難聴をその病
因からして “自律神経性難聴”之総括呼称したい，その 群にはメニェール病及び所謂突発性難聴の大部分（狭義

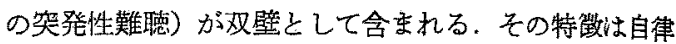
神経失調から常に血管障害を介して感覚器の病变へと進 行するので突発性であることと病態の変化が血管障害の

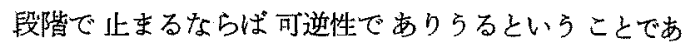
る。また，著渚は所謂騒音性難聴も突発性の例は少ない、 がこの自律神経性難聴の範疇に近い疾患と考えている.

さて, 突発性難㯖が内耳血管障害を介して発定する疾 患と推測されていることから内耳の血行動態に関して近 年多くの研究が集積されている，例之ば，内リンハ液の 分议之吸収, 蝸牛管内の直流電位の維持, コルチ器に対 する酸素供給, 内耳動脈の変異, 出血, 血栓, 柽塞, 毁 脈壁变化，血管運蛙性の疾患に対する意義，過敏症発作 時の内耳血管の反応態度などがそれである.

しかしながら，これらの基礎的知見にす拘らず未だに 臨林的に多くの問題が残されている，何故片側性が多い のか. 幼览や高令者に少ないのか. 何故一回きりの発作 で反復がないのか．聴力変化像に一定性がないのは何故 か. 治療効果はどの程度期待できるものかなどの疑問が ぞのように説明されて行くか今後の課題であろう.そし て現在それらの点に対する解答はすべて推測の段階であ るが，それらの問題を常に念頭に和いて突発性難㯖を䠦 床観察することは大切なととと思われる。

\section{文献}

1) Kobrak, F.: Die angioneurotische Oktavuskrise. Beitr. Z. Anat. Phisiol. Path. Therap. Ohr., 18: 305, $1922 . \quad 2)$ De Kleyn, A.: Sudden Complete or Partial Loss of Function of the Octavus-System in Apparently Normal Persons. Acta Otolaryng., 32: 407, 1944. 3) Rasmussen, H.: Sudden Deafness. Acta Otolaryng., $37: 65,1949.4$ 4) 山㱦芳

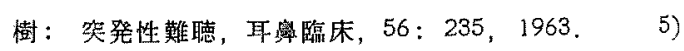
Bosatra, A.B. et al: The Idiopathic Sudden Deafness. A Clinical Study. Acta Otolaryng., Suppl. 169: 1961. 6) Fozeler, E.P.: Sudden Deafness. Ann. Otol., 59: 980, 1950.7 7) Hallberg, O.E.: Sudden Deafness of Obscure Origin. Laryngoscope, 66: 1237, 1956: 8) Svane-Knudsen, V.: Sudden "Spontaneous" Lesion of Aural Function. Acta Otolaryng., 47: 270, 1957 a. . 9) Schroeder, H.O.: Ueber die plötzlich auftretende einseitige Schwerhörigkeit. Z. Laryng., $34: 630,1955,10)$ 㜄口信 


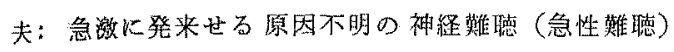

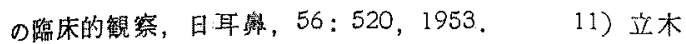

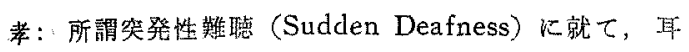
堠科，27：293，1955，12）中村四郎，他：Sudden Deafness の䧗床的 锼察， 耳喉科，31: 331，1959.

13）切替一郎，他：最近遭邀した笑発性炏㯖の臨床的

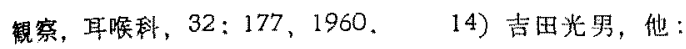
最近6年間の Sudden deafness 0 観察, 耳舅臨床, 55: 199, 1960. 15) Lindsay, J.R. et al: Inner Ear Deafness of Sudden Onset. Laryngoscope, 60 : 238, 1950. 16) Schuknecht, H.F. et al: The Pathology of Sudden Deafness. Laryngoscope, 72 : 1142, 1962. 17) Habermann, 1898 3) 上り引用. 18) Escat, 1906 3) より引用. 19) Saltzman, M. et al: The Ear Stroke. Eye Ear Nose Throat Monthly, 31: 372, 1952.20$)$ Kirikae, I. et al: Sudden Deafness Due to Buerger's Disease. Arch. Otolaryng., 75: 502, 1962. 21) 野末道彦：末来梢迷

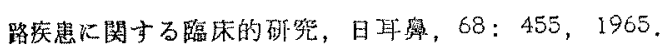

22) Hilger, J.A. et al: Some Aspects of Inner Ear Therapy. Laryngoscope, 61: 695, 1951。23) 津崎

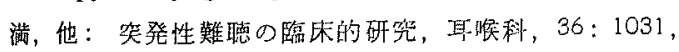
1962. 24) Hilger, J.A.: Vasomotor Labyrinthine Ischemia. Ann. Otol., $59: 1101,1950$. 25) Möller, F. et al: An Accumulation of Cases of Neurogenous Hearing Impairment. Acta Otolaryng., 47 : 158, 1957. 26) Van Dishoeck, H.A.E.: Sudden Perceptive Deafness and Viral Infection. Ann.

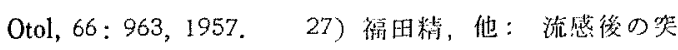
登性難㯖、日耳鬼，61:644, 1958.28) Saunders, W.H.: Sudden Dealness and Bell's Palsy: A Common Cause. Ann. Otol., 68: 830, 1959.

Bocca, E. et al: Sudden Neuritis of the VIIIth Nerve. Arch. ital Otol, 67: 47, 1956. (Abstr. in Excerpt. Med., Sec. XI, Vol. 10, No. 186, 1957).

30) Lindsay, J.R. et al: Inner Ear Pathology in Deafness Due to Mumps. Ann. Otol., 69: 918, 1960. 31) Lindsay, J.R. et al: Inner Ear Pathology Fol lowing Maternal Rubella. Ann. Otol., 62: 1201, 1953. 32) Lindsay, J.R. et al: Inner Ear Pathology Due to Measles. Ann. Otol., 63: 754, 1954. 33）山川強四郎，他：メ二ニール氏病の内耳病理数稿 学, 耳喉科, $27: 820,1955 . \quad$ 34) Opheim, O.:
Acute Cryptogenetic Total Deafness Fenestration. Acta Otolaryng., Suppl, 95: 58, 1951. 35) Mygind, 1947 34) より引用. 36) Nielsen, J.C.: Acute Cryptogenic Deafness Treated by Fenestration. Acta Otolaryng., Suppl., 109:122, 1953. 37) 波

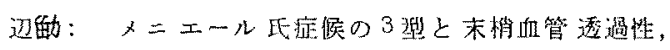
目菆受，55:777，1952. 38) Lenhardt, E.: Zur Pathogenese plötzlicher Hörstörungen. Deutsch Gesundh. Wes., 13:105, 1958. 39) 位藤恒正: 妊

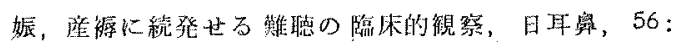
828, 1953, 40) Fuchs, A.M. et al: Allergic Deafness. N.Y. St. J. Med., 47 : 1397, 1947.41 ) Ebert, R.H. et al: In Vivo Observations of the Vascular Reactions to Large Doses of Horse Serum Using the Rabbit Ear Chamber Technique. J. Lab. Clin. Med., 38: 511, 1951. 42) Weille, F.L. et al: An Experimental Study of the Small Blood Vessels of the Spiral Ligament and Stria Vascularis of Living Guinea Pigs during Anaphylaxis. Laryngoscope, 64: 656, $1954 . \quad$ 43) Irwin, J.W. et al: Small Blood Vessels during Allergic Reactions. Ann. Otol., 64: 1164, 1955. 44) Perlman, H.B. et al: Observations of the Living Blood Vessels of the Cochlea. Ann. Otol, 65: 1176, 1955.4 45) Terayama, Y. et al: Studies on Experimental Allergic (Isoimmune) Labyrinthitis in Guinea Pig. Acta Otolaryng., 58: 49, 1964. 46) Heller, M.F. et al: Sudden Perceptive Deafness. Ann. Otol., 64 : 931, 1955. 47) Beichert, P: Plötzlich auftretende einseitige Ertaubung und ihre Behandlung. (psychoemotionelle und zervikale Genese.) Z. Laryng., 35: 384, 1956. 48) Hallberg, O.E.: Sudden Deafness and Its Relation to Anerosclerosis. JAMA, 165: 1649, 1957. 49) Van Caneghem, D.: Sudden Deafness. Acta Otolaryng., Belg., 12: 5, 1958. Abstr. in Excerpt. Med. Sec. XI, 12: 1077: 1959. 50) Debain, J.: Les surdités brusques. Sem. Hop. Paris, 34: 599, 1958. 51) Wilmot, T.: Sudden Perceptive Deafness in Young People. J. Laryng., 73 : 466, 1959. 52) Walander, A. et al: Transitory Acute Unilateral Perceptive Deafness. Acta Otolaryng., 51:485, $1960 . \quad$ 53) Moe, $R$ : Transitory Deafness. Acta Otolaryng., 35: 20, $1947 . \quad 54)$ 
Sterkers, J: Causes et traitements des surdités brusques. Sem. Hop. Paris, 32 : 856, $1955 . \quad 55)$ Svane-Knudsen, V.: Intracranial Findings in a Late Case of Acute, "Idiopathic" Deafness. Acta Otolaryng., 47: 459, 1957. 56) Bierman, 1957. 16) より引用. 57) Brown, L.A.: Acoustic Accident. Laryngoscope, 67: 238, $1957 . \quad 58)$ Lieberman, A.T.: Unilateral Deafness. Laryngoscope, 67: 1237 , 1957. 59) Lindsay, J.R.: Sudden Deafness Due to Virus Infection. Arch. Otolaryng., 69: 13, 1959. 60) Jerger, J. et al: Hearing Loss of Sudden Onset. Arch. Otolaryng., 73: 350, 1961. 61) Harbert, F. et al: Sudden Deafness with Complete Recovery. Arch. Otolaryng., 79: 459, 1964. Mygind, S.H.: Discussion. Acta Otolaryng., Suppl. 95: 68, 1951. 63) Lawrence, M.: Functional Changes in Inner Ear Deafness. Ann. Otol., 67: 802, 1958. 64) Nabeya, D.: A Study in the Comparative Anatomy of the Blood Vascular System of the Internal Ear in Mammalia and in Homo. Acta Scholae Med., 6: 1, $1923 . \quad 65)$ Smith, C.: Capillary Areas of the Cochlea in the Guinea Pig. Laryngoscope, 61: 1073, 1951. 66) Smith, C.: Capillary Areas of the Membranous Labyrinth. Ann. Otol., 63: 435, $1954 . \quad 67)$ Hallberg, O.E. et al: Sudden Deafness Due to Cerebellopontine-Angle Tumor. Arch. Otolaryng., 69: 160, 1959. 68) Dubs, R.: Traumatic Embolus of the Internal Auditory Artery. Pract. Otorhinolaryng., 18: 334, 1956. 69) Lorente de No, R.: The Sensory Endings in the Cochlea. Laryngoscope, 47 : 373, $1937 . \quad$ 70) Fernández, C.: Innervation of the Cochlea in Relation to Hearing Loss. Laryngoscope, 70: 363, 1960. 71) Seymour, J.C. et al: Some Aspects of tee Sympathetic Nervous System in Rilation to the Inner Eer. Acta Otolaryng., 43: 618, 1953. 72) Nomura, Y.: Observations on the Microcirculation of the Cochlea. Ann. Otol, 70: 1037, 1961. 73) Seymour, J.C.: Observations on the Circulation in the Cochlea. J. Laryng., 68; 689, $1954 . \quad$ 74) Perlman, H.B.: Experimental Obstruction of the Venous Drainage and Arterial Supply of the Inner Ear. Ann. Otol., 66:537, 1957.
75) Mygind, S.H.: Experimental Histological Studies on the Labyrinth. IX. Histamine and Adrenaline. Acta Otolaryng., 34: 59, 1946. 76) 洞圭三:

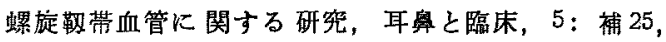
1959. 77) 菅野享, 他：内耳末 梢血管生態観察 に㧍ける2,3の問題，Audiology, 6: 110, 1963. 78) Perlman, H.B. et al: Cochlear Blood Flow and Function: Effect of Pressor Agents. Acta Otolaryng., 56:587, 1963. 79) 長會政行：内耳血管 の自律神経支配に関する組織化学的研觉，日耳㗤，67: 1251, 1964. 80) Perlman, H.B. et al: Experiments on Temporary Obstruction of the Internal Auditory Artery. Laryngoscope, 69: 591, 1959.

81) Kimura, R. et al: Arterial Obstruction of the Labyrinth. Ann. Otol. $67: 5,1958$. 82) Kimura, R. et al: Extensive Venous Obstruction of the Labyrinth. A. Cochlear Changes. Ann. Otol., 61: 332, 1956. 83) Hughson, W. et al: Research in Audition. Arch. Otolaryng., 29 : 903, $1939 . \quad 84)$ Gisselsson, 1949 89) より引用. 85) Wever, E.G. et al: Effects of Oxygen Deprivation upon the Cochlear Potentials. Amer. J. Physiol., 159: 199, 1949. 86) Bornschein, H. et al: Der Einfluss künstlicher Durchströmung auf den postmortalen Schwund der Cochlearpotentiale. Experientia, 6: 67, 1950. 87) Wing, et al: 1952 91) より引用.

88) Gisselsson, L.: The Effect of Oxygen Lack and Decreased Blood Pressure on the Microphonic Response of the Cochlea. Acta Otolaryng., 44:101, 1954. 89) Fernandez, C.: The Effect of Oxygen Lack on Cochlear Potentials. Ann. Otol., 64 : 1193 , 1955. 90) Gulick, W.L.: The Effects of Hypoxemia upon the Electrical Response of the Cochlea. Ann. Otol, 67 : 148, 1958. 91) Bornschein, H. et al: Selective Removal of the Nerve Discharge Component from the Cochlear Potential during Anoxia. Acta Physiol., 21 : 82, 1950.92$)$ Fernán. dez, C. et al: Modifications of Cochlear Responses by Oxygen Deprivation. Arch. Otolaryng., 69: 82, 1959. 93) Konishi, T. et al: Effect of Anoxia on Cochlear Potentials. JASA., 33: 349, 1961. 94) Von Békesy, G.: Gross Localization of the Place of Origin of the Cochlear Microphonics. JASA, 
$24: 399,1952$.

95) Gisselsson, L.: Neuere Probleme des Cochleaeffektes. Arch. Ohr. Nas. Kehlkn. opfh., 167: 274, 1955.

96) 志多孛：強大音と Endolymphatic Potential (EP) Audiology, 8: 1, 1965. 97) Lawrence, $M$. et al: Effects of Oxygen Deprivation upon the Structure of the Organ of Corti. Arch. Otoloaryng., 55: 31, 1952, 98) FalbeHansen, $J_{\text {:: }}$ Effect of Acute and Prolonged Oxygen Deprivation on the Organ of Corti in Guinea Pigs and Cats. Arch. Otolaryng., 67: 71, 1958.99 ) Perlman, H.B.: Experimental Occlusion of Inferior Cochlear Vein. Ann. Otol., 58: 33, 1952. Seymour, J.C. et al: The Effect of Sympathetic Stimulation upon the Cochlear Microphonic Potentials. Proc. roy. Soc. Med., 44: 755, 1951.

Rambo, J.H.T. et al: A Research Study of the Effect of the Autonomic Nervous System in the Internal Ear. Ann. Otol., 62: 1149, 1953. 102) 丸

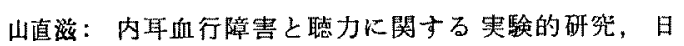
耳鼻, 59:717, 1956. 103) Hughson, W. et al:

Experimental Investigation of the Physiology of the Ear. Acta Otolaryng., 18: 281, 1933.104$)$ Von Békésy, G.: Ueber die Schwingungen der Schneckentrennwand beim Praeparat und Ohrmodell. Akust. Z. $7: 173,1942$. 105) Lempert, J. et al: Perilymph: Its Relation to the Improvement of Hearing Which Follows Fenestration of the Improvement of Hearing Which Follows Fenestration of the Vestibular Labyrinth in Clinical Otosclerosis. Arch. Otolaryng., 50:377, 1949. 106) 圾本秀 生：内耳医の実験的研究，耳喉科，24：149，1952.

107) Hallpike, C.S.: Observations of the Pathology of Ménière's Syndrome. J. Laryng., 53: 625, 1938.

108) Golding-Wood, P.H.: Ménière Disease nd Its Pathological Mechanism. J. Laryng., 74: 803, 1960. 109) Mygind, S.H.: Experimental-Histological Studies on the Labyrinth. XI. Correlation of Our Histological and Clinical Experiments and Observations. Acta Otolaryng., 35: 108, 1947.

Lindsay, J.R.: Labyrinthine Dropsy and Ménière's Disease. Arch. Otolaryng., 35: 853, 1942. Lindsay, J.R.: Labyrinthine Dropsy. Laryngoscope, $56: 325,1964$.

112) Tonndorf, J.: The Me- chanism of Hearing Loss in Early Cases of Endolymphatic Hydrops. Ann. Otol., 66: 766, 1957.

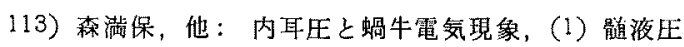
变化と蝸作電気現象，Audiology, 7: 115, 1964. 114) Schuknecht, H.F. et al: On Experimental and Clinical Study of Deafness from Lesions of the Cochlear Nerve. J. Laryng., 69: 75, 1955.115 ) Ruben, R.J. et al: Anatomical and Physiological Effects of Chronic Section of the Eight Nerve in Cat. Acta Otolaryng., 55: 473, 1962 . 116) Dandy, W.E.:

Effect on Hearing after Subtotal Section of the Cochlear Branch of the Auditory Nerve. Bull. John Hopk. Hosp., 55: 240, $1934 . \quad 117)$ Neff, W.D.: Effects of Partial Section of Auditory Nerve. J. comp. physiol. Psychol,, 40: 203, 1947.

118) Schuknecht, H.F. et al: Hearing Losses Following Partial Section of the Cochlear Nerve. Laryngoscope, 63: 441, 1953 . 119) Kiang, N.Y. et al: Components of Electrical Responses Recorded from the Cochlea. Ann. Otol., 69: 448, 1960. 120) Fisch, U,P. et al: Electrical Acoustical Response to Click Stimulation after Section of the Eighth Nerve. Acta Otolaryng., 54: 531, 1962. 121) 片桐主一，他：第 8 媨神経切断の螖牛電位及び聴 神経活動電位に及仿寸影響，Audiology, 7：183, 1964. 122) 切替一郎, 他: Sudden Deafness の聴力型につ いて, 耳䐅科，35:437，1963. 123) Williams, H,L. et al: Endolymphatic Hydrops without Vertigo. Arch. Otolaryng., 51: 557, 1950. 124）切替一郎, 他：㔖発性奞聴の予後，Audiology，8：115，1965. 125）渡辺蛋：急激に発来した片侧感音系難㯖の観察，

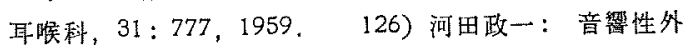

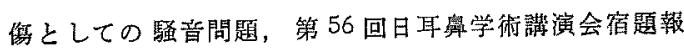
告, 1955. 127) Von Békésy, G.: Ueber die Elastizitaet der Schneckentrennwand des Ohres. Akust. Z. 6:265, 1941. 128) Smith, C.A.: Innervation Pattern of the Cochlea. Ann. Otol., 70: 504, 1961. 129) Kimura, R. et al: Termination of the OlivoCochlear Bundle in Relation to the Outer Hair Cells of the Organ of Corti in Guinea Pig. Acta Otolaryng., 55: 11, $1962 . \quad$ 130) Erulkar, S.D. et al: Carbonic Anhydrase and the Inner Ear. Nature, 189:459, 1961. 131$)$ Tasaki, I. et al: The 
Space-Time Pattern of the Cochlear Microphonics (Guinea-Pig) As Recorded by Differential Electrode. JASA., 24: 502, 1952. 132) 山崳芳樹：突発性 難聴例の前庭機能に就いて，耳鼻之臨休，4:149，1958， 133）佐藤武男，他：Sudden Deafness について，耳 率臨床, 50:753, 1957。134) 切替一郎, 他; 感音

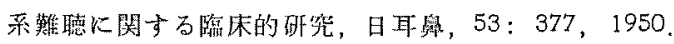

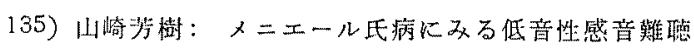

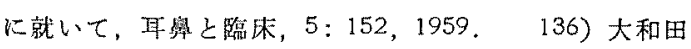
健次郎，他：急性感者難聴の回復過程について，耳嶰 科，31：239，1959。137）山崎芳樹：实発性難聴の 星状神経節遮断療法について，耳鼾々臨床，4：154, 1958. 138) 松本勝男: 小わゆる突発性難聴の二治 験例，耷䁷臨床，52：1959。139）武末正義：低音

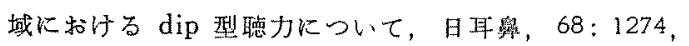

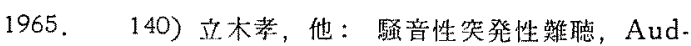
iology, 6: 152, 1963. 141) 河田政一, 他: Industrial Sudden Deafness の提唱と艺臨林像, Audiology, 6: 154, 1963. 142) 橋本泰榇, 他：最近の笑発 性蜼悖 (Sudden Deafness) 飞就いて，耳喉科，29: 1002, 1957. 143) 南立純一郎, 他: 哭登難聴, 年 と臨床，7：1，1961。144）切替一郎，他：Sudden Deafness $の$ 病変部位, 耳喉科, 36:213, 1964, 145) Shambaugh, G.E. et al: Report of an Investigation of Ten Cases of Diplacusis. Tr. Amer. Otol. Soc., 16: 397, 1923. 146) Shambaugh, G.E. Jr.: Syndrome of Diplacusis and Nerve Deafness for Low Tones. Arch. Otolaryng., 21 : 694, 1935. Shambaugh, G.E. $J_{r}$.: Diplacusis: A Localizing Symptom of Disease of the Organ of Corti. Arch. Otolaryng., 31 : 160, $1940 . \quad 148)$ Eby, L.G. et al: Recruitment of Loudness in the Differential Diagnosis of End-Organ and Nerve Fibre Deafness. Laryngoscope, 56: 400, 1951. 149) Albers, G.D.: Diplacusis. 日耳率, 68: 1345, 1965. 150) Webster, J.C. et al: Pitch Shifts Accompanying Certain Auditory Threshold Shift. JASA, 26: 754, 1954. 151) Ward, W.D.: Auditory Fatigue and Masking. In "Modern Development of Audiology". Editor by Jerger, J., Acad. Press. New York, p. 240, 1963. 152) Von Békésy G.: Experiment in Hearing. Editor by Wever, E.G., McGraw-Hill Comp., London p. 366, 1960 . 153) Rüedi, L. et al: Akustisches Trauma und Funktion des Innenohres. Acta Otolaryng., 33: 460, $1945 . \quad$ 154) Davis, H. et al: Diplacusis. Acta Otolaryng., Suppl., 88: 44, 1950. 155) De Mare, G.: Investigations into the Funct. ions of the Auditory Apparatus in Perception Dea. fness. Acta Otolaryng., Suppl. 74: 107, 1948. 156) 寺尾彬：両耳噹に扣ける音像移動弁別閾值に関寸る研 㤎，日耳鼻，67:982，1964。 157) David, E.E. Jr. et al: On the Mechanism of Binaural Fusion. JASA., 30: 801, 1958. 158) Deatherage, B.H. et al: Auditory Localization of Clicks. JASA., 31 : 486, 1959 . 159) Sanchez-Longo, L.P. et al: Clinical Test for Sound Localization and Its Applications. Neurology, 7: 655, 1957. 160) SanchezLongo, L.P. et al: Clinical Significance of Impairment of Sound Localization. Neurology, 8: 119 , 1958, 161) Matzker, J.: Two New Methods for the Assessment of Central Auditory Functions in Cases of Brain Disease. Ann. Otol., 68: 1185, 1959. 162) Bocca, E. et al: Central Hearing Processes. In "Modern Developments of Audiology". Editor by Jerger, J., Acad. Press, New York, p. 337, 1963. 163) 侁藤恒正, 他：音刺滶頻度の把掇能力について, Audiology，8：111，1965.164) 酒井俊一：耳科

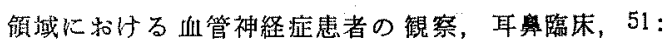
381，1958．165) 中野雄一：血行遮断比よる内耳糖 代謝の受觔性に関する研焭，耳鼻監床，54:909，1961。 166) 後藤修二, 他：梨音と聴器, Audiology, 6: 102, 1963 .

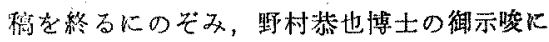
梁謝致します。

（原稍到薪 $=$ 炤和 41.1 .21 日） 